Marquette University

e-Publications@Marquette

Physical Therapy Faculty Research and Publications

Physical Therapy, Department of

2-2011

\title{
The Effects of Lesions in the Dorsolateral Pons on the Coordination of Swallowing and Breathing in Awake Goats
}

Joshua M. Bonis

Medical College of Wisconsin

S. E. Neumueller

Medical College of Wisconsin

B. D. Marshall

Medical College of Wisconsin

K. L. Krause

Medical College of Wisconsin

B. Qian

Medical College of Wisconsin

See next page for additional authors

Follow this and additional works at: https://epublications.marquette.edu/phys_therapy_fac

Part of the Physical Therapy Commons

\section{Recommended Citation}

Bonis, Joshua M.; Neumueller, S. E.; Marshall, B. D.; Krause, K. L.; Qian, B.; Pan, Lawrence; Hodges, M. R.; and Forster, Hubert V., "The Effects of Lesions in the Dorsolateral Pons on the Coordination of Swallowing and Breathing in Awake Goats" (2011). Physical Therapy Faculty Research and Publications. 48.

https://epublications.marquette.edu/phys_therapy_fac/48 
Authors

Joshua M. Bonis, S. E. Neumueller, B. D. Marshall, K. L. Krause, B. Qian, Lawrence Pan, M. R. Hodges, and Hubert V. Forster

This article is available at e-Publications@Marquette: https://epublications.marquette.edu/phys_therapy_fac/48 


\title{
The Effects of Lesions in the Dorsolateral Pons on the Coordination of Swallowing and Breathing in Awake Goats
}

\author{
J.M. Bonis \\ Department of Physiology, Medical College of Wisconsin \\ Milwaukee, WI \\ S.E. Neumueller \\ Department of Physiology, Medical College of Wisconsin \\ Milwaukee, WI \\ B.D. Marshall \\ Department of Physiology, Medical College of Wisconsin \\ Milwaukee, WI \\ K.L. Krause \\ Department of Physiology, Medical College of Wisconsin \\ Milwaukee, WI \\ B. Qian \\ Department of Physiology, Medical College of Wisconsin \\ Milwaukee, WI \\ L.G. Pan \\ Marquette University, Department of Physical Therapy \\ Milwaukee, WI
}

Respiratory Physiology \& Neurobiology, Vol 175, No. 2 (February 15, 2011): pg. 272-282. DOI. This article is (C Elsevier and permission has been granted for this version to appear in e-Publications@Marquette. Elsevier does not grant permission for this article to be further copied/distributed or hosted elsewhere without the express permission from Elsevier. 
NOT THE PUBLISHED VERSION; this is the author's final, peer-reviewed manuscript. The published version may be accessed by following the link in the citation at the bottom of the page.

\author{
M.R. Hodges \\ Department of Physiology, Medical College of Wisconsin \\ Milwaukee, WI \\ H. V. Forster \\ Department of Physiology, Medical College of Wisconsin \\ VA Medical Center \\ Milwaukee, WI
}

\begin{abstract}
The purpose of this retrospective study was to gain insight into the contribution of the dorsolateral pons to the coordination of swallowing and breathing in awake goats. In 4 goats, cannulas were chronically implanted bilaterally through the lateral (LPBN) and medial (MPBN) parabrachial nuclei just dorsal to the Kölliker-Fuse nucleus (KFN). After $>2$ wks recovery from this surgery, the goats were studied for $51 / 2 \mathrm{hrs}$ on a control day, and on separate days after receiving 1 and $10 \mu$ injections of ibotenic acid (IA) separated by $1 \mathrm{wk}$. The frequency of swallows did not change during the control and $1 \mu \mathrm{l}$ IA studies, but after injection of $10 \mu \mathrm{IA}$, there was a transient $65 \%$ increase in frequency of swallows $(P<0.05)$. Under control conditions swallows occurred throughout the respiratory cycle, where late-E swallows accounted for $67.6 \%$ of swallows. The distribution of swallow occurrence throughout the respiratory cycle was unaffected by IA injections. Consistent with the concept that swallowing is dominant over breathing, we found that swallows increased inspiratory $\left(T_{I}\right)$ and expiratory $\left(T_{E}\right)$ time and decreased tidal volume $\left(\mathrm{V}_{\mathrm{T}}\right)$ of the breath of the swallow $(n)$ and/or the subsequent $(n+1)$ breath. Injections of $10 \mu \mathrm{l}$ IA attenuated the normal increases in $\mathrm{T}_{\mathrm{I}}$ and $\mathrm{T}_{\mathrm{E}}$ and further attenuated $\mathrm{V}_{\mathrm{T}}$ of the $n$ breath. Additionally, $\mathrm{E}$ and I swallows reset respiratory rhythm, but injection of 1 or $10 \mu$ IA progressively attenuated this resetting, suggesting a decreased dominance over respiratory motor output with increasing IA injections. Post mortem histological analysis revealed about $50 \%$ fewer $(P<0.05)$ neurons remained in the KFN, LPBN, and MPBN in lesioned compared to control goats. We conclude that dorsolateral pontine nuclei have a modulatory role in a hypothesized holarchical neural network regulating swallowing and breathing particularly contributing to the normal dominance of swallowing over breathing in both rhythm and motor pattern generation.
\end{abstract}

\title{
2 Introduction
}

Neuromechanical coordination of breathing and swallowing is essential, as both functions share common neurological and

Respiratory Physiology \& Neurobiology, Vol 175, No. 2 (February 15, 2011): pg. 272-282. DOI. This article is @ Elsevier and permission has been granted for this version to appear in e-Publications@Marquette. Elsevier does not grant permission for this article to be further copied/distributed or hosted elsewhere without the express permission from Elsevier. 
oropharyngolaryngeal anatomy. The neuromechanical coupling is critical for proper feeding and execution of mucociliary clearance (Schindler A. et al., 2008; Matsuo K. et al., 2009). Loss of this coordination may result in aspiration leading to bacterial infection, aspiration pneumonia, pulmonary fibrosis, malnutrition, dehydration, and/or developmental deficits, particularly in children (Prasse J. et al., 2009). Implicit in proper coordination is efficient performance of each behavior with limited compromise of the alternate behavior. In other words, deglutition should minimally alter breathing, breathing should not delay delivery of a bolus to the stomach, and both behaviors should be performed with minimal energy expenditure.

Despite its importance, the neurological sites involved in the coordination between breathing and swallowing, and for other behaviors (vomiting, coughing, etc.) utilizing the same muscles and oropharyngolaryngeal anatomy, are not well understood. One proposed site contributing to this coordination is the Kölliker-Fuse nucleus (KFN) in the rostral pons (Gastreau C. et al, 2005). The role of the KFN and the lateral (LPBN) and medial (MPBN) parabrachial nuclei in the dorsolateral pons in respiratory rhythm and pattern generation has long been recognized, confirmed recently by Abdala et al. who found that these sites contributes to the generation of the three-phase eupneic pattern, as sequential transections through the pons eliminated phase 2 of the normal, eupneic, inspiration, postinspiration, and active expiration respiratory patterns (Abdala A. et al., 2009). The importance of the dorsolateral pons was further demonstrated by the effect of neurotoxic lesions of this area in unanesthetized, awake goats which had a biphasic effect on pulmonary ventilation, accompanied by apneic and apneustic-like breathing patterns (Bonis J.M. et al., 2010b).

In addition to respiratory control, the data of Gestreau and colleagues provide evidence for a role of the KFN in the coordination of breathing and swallowing. Electrolytic lesions of the intermediate portion of the KFN in decerebrate rats augmented hypoglossal activity associated with swallowing (Gestreau C. et al., 2005). Based on these results, the authors theorized that the mechanism for this augmentation was a disinhibition of surviving pontine hypoglossal premotor neurons spared by the electrolytic lesion (Gestreau C. et al., 2005). This postulate fits with other observations, where glutamate

Respiratory Physiology \& Neurobiology, Vol 175, No. 2 (February 15, 2011): pg. 272-282. DOI. This article is (C) Elsevier and permission has been granted for this version to appear in e-Publications@Marquette. Elsevier does not grant permission for this article to be further copied/distributed or hosted elsewhere without the express permission from Elsevier. 
injections into the intermediate KFN attenuated hypoglossal activity associated with swallowing, and in addition, with inspiratory activities of the hypoglossal nerve and external intercostal muscles (Gestreau C. et al., 2005).

The purpose of the retrospective analyses reported herein was to examine the effects of spontaneous, solitary swallows on respiratory output and timing in unanesthetized, awake goats instrumented with chronically placed cannulas through the LPBN and MPBN just dorsal to the KFN. The analyses were retrospective in that the study was designed to examine the effects of dorsolateral perturbations on the control of breathing (Bonis J.M. et al., 2010b). Based on past studies referred to above, we hypothesized that injection of ibotenic acid into the dorsolateral pons would 1) alter the frequency of occurrence of swallows relative to control conditions, 2) attenuate any resetting of respiratory phase observed under control conditions, and 3) alter ventilatory output parameters relative to control conditions, particularly for swallows occurring during the inspiratory phase.

\section{Methods}

We used adult goats for our studies due to their large size, which permitted chronic implantation of stainless steel cannulas into the brainstem and enabled microinjection into target sites during the awake state. Furthermore, our laboratory has considerable background data concerning respiratory rhythm and pattern generation (Krause K. et al., 2009; Martino P. et al., 2007; Wenninger J et al., 2004) and coordination of breathing and swallowing (Feroah T. et al., 2002a and $2002 b$ ) in goats.

Physiologic data were acquired from 4 female adult goats, weighing $46.4 \pm 6.8 \mathrm{~kg}$. Six additional goats were used for histological purposes only $(44.1 \pm 2.9 \mathrm{~kg})$. Goats were housed and studied in an environmental chamber with a fixed ambient temperature and photoperiod. All goats were allowed free access to hay and water, except during periods of study. All aspects of the study were reviewed and approved by the Medical College of Wisconsin Animal Care Committee before the studies were initiated.

Respiratory Physiology \& Neurobiology, Vol 175, No. 2 (February 15, 2011): pg. 272-282. DOI. This article is (C) Elsevier and permission has been granted for this version to appear in e-Publications@Marquette. Elsevier does not grant permission for this article to be further copied/distributed or hosted elsewhere without the express permission from Elsevier. 


\subsection{Experimental design, protocols, and surgical procedures}

Data were obtained from goats that were studied as part of a larger experimental series that determined the effects of attenuating cholinergic modulation through microdialysis of atropine (Bonis J.M. et al., 2010a), and the effects of neurotoxic lesions in the dorsolateral pons on respiratory rhythm and pattern in an in vivo awake/asleep animal (Bonis J.M. et al., 2010b). Thus, the experimental design and surgical procedures have been reported previously (Bonis J.M. et al., 2010b). Briefly, each goat underwent an initial instrumentation surgery in which electromyographic (EMG) electrodes were implanted into the posterior cricoarytenoid (PCA), genioglossus (GG), thyroid arytenoid (TYA), thyropharyngeus (TP), diaphragm, and transverse abdominal muscles, and a $5 \mathrm{~cm}$ segment of carotid arteries lifted to subcutaneous levels for ease of arterial blood gas sampling. At least two weeks later, in a second surgery, cannula were bilaterally implanted through the LPBN and MPBN to just dorsal to the KFN in the dorsolateral pons. The cannula implantations required a single occipital craniotomy created through a posterior midline incision after which the dura mater was excised to expose the posterior cerebellum and medulla for visualization of obex. To standardize stereotaxic coordinates, the orientations of the dorsal medullary surface, obex, and midline were used to determine the dorsoventral, rostrocaudal, and mediolateral planes. To avoid the superior sagittal sinus, an angled approach was adopted whereby cannulas were inserted caudal to the confluence of the sinus, through the mid-cerebellum, at angles of $10.5-24^{\circ}$ from normal (relative to the dorsal medullary surface). The coordinates for individual goats varied with their size and ranged from $0-2 \mathrm{~mm}$ ventral, $4-5 \mathrm{~mm}$ lateral, and $20-24 \mathrm{~mm}$ rostral to respective reference points. After placement, cannulas were anchored to the surrounding bone using screws and dental acrylic.

After both surgeries, animals were allowed to recover for $\geq$ 2 wks before being studied. After completing cholinergic modulation experiments referred to earlier, control studies were performed in which eupneic breathing and spontaneous swallows were recorded for at least 5 1/2hrs while breathing room air. On subsequent days, injection protocols consisted of a $30 \mathrm{~min}$ control period followed by two

Respiratory Physiology \& Neurobiology, Vol 175, No. 2 (February 15, 2011): pg. 272-282. DOI. This article is @ Elsevier and permission has been granted for this version to appear in e-Publications@Marquette. Elsevier does not grant permission for this article to be further copied/distributed or hosted elsewhere without the express permission from Elsevier. 
unilateral (ipsilateral, then contralateral) microinjections ( 1 or $10 \mu \mathrm{l}$ ) through the chronically implanted cannulas of ibotenic acid (IA, $50 \mathrm{mM})$, an irreversible glutamate receptor agonist and excitotoxin. Small injection tubes were preloaded with IA and inserted into the cannulas, such that the injection was made directly at the distal-most aspect of the cannulas without penetrating the tissue. These injections were separated by at least an hour or until breathing frequency was stable. The total study time was $51 / 2 \mathrm{hrs}$, and the 1 and then $10 \mu \mathrm{l}$ IA injections were separated by $1 \mathrm{wk}$. Seven days after the large volume IA injection the animal was euthanized and histological analyses were performed on the brainstem.

\subsection{Data analyses}

Pulmonary ventilation $\left(\mathrm{V}_{\mathrm{I}} ; \mathrm{l} / \mathrm{min}\right)$, breathing frequency ( $\mathrm{f}$; breaths/min), tidal volume $\left(\mathrm{V}_{\mathrm{T}} ; \mathrm{l} /\right.$ breath $)$, expiratory $\left(\mathrm{T}_{\mathrm{E}} ; \mathrm{s}\right)$ and inspiratory $\left(\mathrm{T}_{\mathrm{I}} ; \mathrm{s}\right)$ times, and diaphragm, abdominal, and PCA muscle activities ( $\mathrm{mV}$ ) were analyzed on a breath-by-breath basis. Respiratory muscle activity was recorded via Windaq using the chronically implanted EMG electrodes. The airflow signal was calibrated against a known airflow value, whereas the EMG baseline was set to zero. Calibrated airflow and zeroed EMG signals were rectified and time averaged ( $0.33 \mathrm{~s}$ time constant). During the experimental control periods, these rectified and time averaged signals were used to recalibrate the EMG signals with the assignment of arbitrary peak (1) and baseline $(0)$ values. These recalibrated signals were again rectified and time averaged. From the calibrated airflow values for each breath, $\mathrm{V}_{\mathrm{T}}$ was calculated. Using the recalibrated airway muscle EMG signal, a new baseline value was arbitrarily assigned just above the normal basal activity, so as to produce a signal in which only the activity of swallows was present. The airflow and EMG signals were converted to a .txt file and input into a custom-designed program that output all parameters on a breath-by-breath basis.

Ventilation was analyzed using the processed airflow signal as described above. We defined the occurrence of inspiration (I) when airflow was greater than $0.01 \mathrm{l} / \mathrm{s}$ for at least $0.2 \mathrm{~s}$ in duration, and the occurrence of expiration ( $E$ ) when airflow returned to zero $\mathrm{l} / \mathrm{s}$ for at least $0.3 \mathrm{~s}$. The respiratory cycle was defined as an I followed by an $\mathrm{E}$,

Respiratory Physiology \& Neurobiology, Vol 175, No. 2 (February 15, 2011): pg. 272-282. DOI. This article is (c) Elsevier and permission has been granted for this version to appear in e-Publications@Marquette. Elsevier does not grant permission for this article to be further copied/distributed or hosted elsewhere without the express permission from Elsevier. 
with the total time ( $T_{\text {Tot }}$ ) calculated as the sum of $T_{I}$ and $T_{E} . T_{I} / T_{\text {Tot }}$ and $\mathrm{V}_{\mathrm{T}} / \mathrm{T}_{\mathrm{I}}$ were also calculated. Breaths were categorized as "quiet," regular breaths or those that were "irregular/disrupted," characterized by respiratory muscle activity caused by swallowing, coughing, mastication, and eructation, or any other abnormal behavior, based on the previously defined categorization (Bonis J.M. et al., 2010b). In addition to the respiratory variables reported above, for each breath the presence of one or more swallows and the timing parameters of the swallow(s) relative to the corresponding respiratory cycle were also analyzed.

Since data reported herein were a retrospective analysis of swallows, the gain of the airway muscle activity was not set to quantify the magnitude of the burst in activity caused by swallows, but the gain was set to detect phasic respiratory-related airway muscle activity; thus, the much larger swallow-related activity was always clipped. As a result, we were unable to complete a retrospective quantification of swallow-related airway muscle activity. We always recorded activity of the PCA airway muscle and we processed this EMG signal for analysis of swallows. Activity of at least one additional airway muscle (GG, TYA, or TP) (Fig. 1) was also recorded, but not processed other than visual verification of the swallow. The processed PCA signal had no baseline activity; thus, a swallow was considered to have occurred when the signal was greater than $0.01 \mathrm{mV}$ for 0.2 to $0.5 \mathrm{~s}$ in duration. The start of the swallow was defined as the beginning of the signal which met these criteria. To be considered solitary, a single swallow must have occurred within the fourth breath of a sixbreath set (Fig. 2A). This breath containing the swallow was labeled the $n$ breath, with preceding $(n-1, n-2$ and $n-3)$ and succeeding $(n+1$ and $n+2)$ breaths labeled accordingly (Fig. 2A). The first, second, and sixth breaths served as controls. The "quiet" and "disrupted" breath categorizations were used such that only the $n$ breath was "disrupted," while the other 5 breaths of the 6 breath set were "quiet", ensuring that swallows due to coughing, mastication, eructation, etc. were not included for further analysis.

Respiratory Physiology \& Neurobiology, Vol 175, No. 2 (February 15, 2011): pg. 272-282. DOI. This article is (C) Elsevier and permission has been granted for this version to appear in e-Publications@Marquette. Elsevier does not grant permission for this article to be further copied/distributed or hosted elsewhere without the express permission from Elsevier. 
NOT THE PUBLISHED VERSION; this is the author's final, peer-reviewed manuscript. The published version may be accessed by following the link in the citation at the bottom of the page.

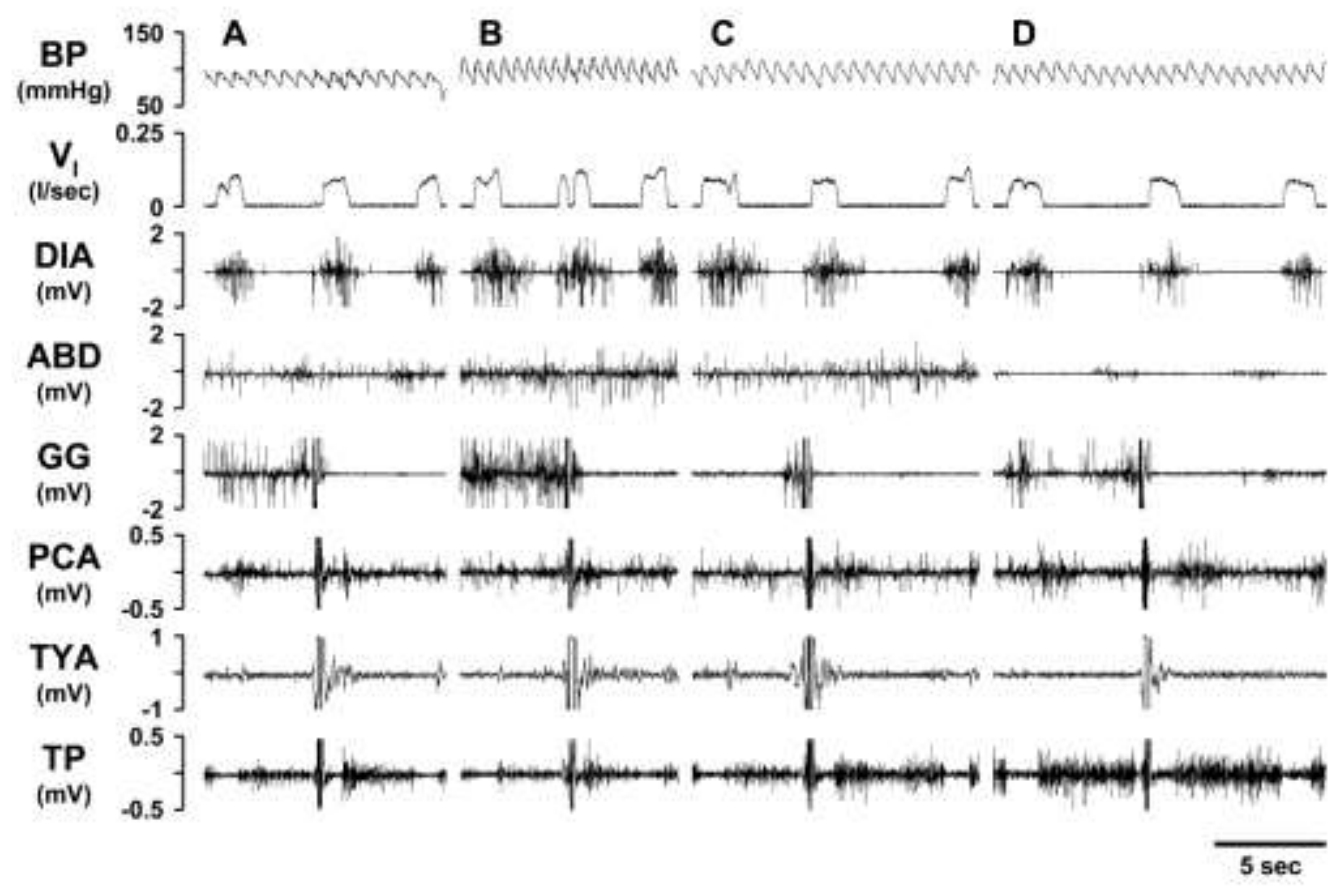

Figure 1. Respiratory motor output of spontaneous, solitary swallows during the control period (Panel A), post-ipsilateral 10 $\mu$ l ibotenic acid (IA) injection (Panel B), post-contralateral $10 \mu \mathrm{l}$ IA injection (Panel C), and at a point near the end of the study (Panel D). The motor pattern of a swallow is in part characterized by the near simultaneous deflection in the genioglossus (GG), posterior cricoarytenoid (PCA), thyroid arytenoid (TYA), and thyropharyngeus (TP) muscle signals, identifiable in each Panel. Blood pressure (BP), pulmonary ventilation (VI), diaphragm (DIA) and abdominal (ABD) muscle activity.

Respiratory Physiology \& Neurobiology, Vol 175, No. 2 (February 15, 2011): pg. 272-282. DOI. This article is (C) Elsevier and permission has been granted for this version to appear in e-Publications@Marquette. Elsevier does not grant permission for this article to be further copied/distributed or hosted elsewhere without the express permission from Elsevier. 

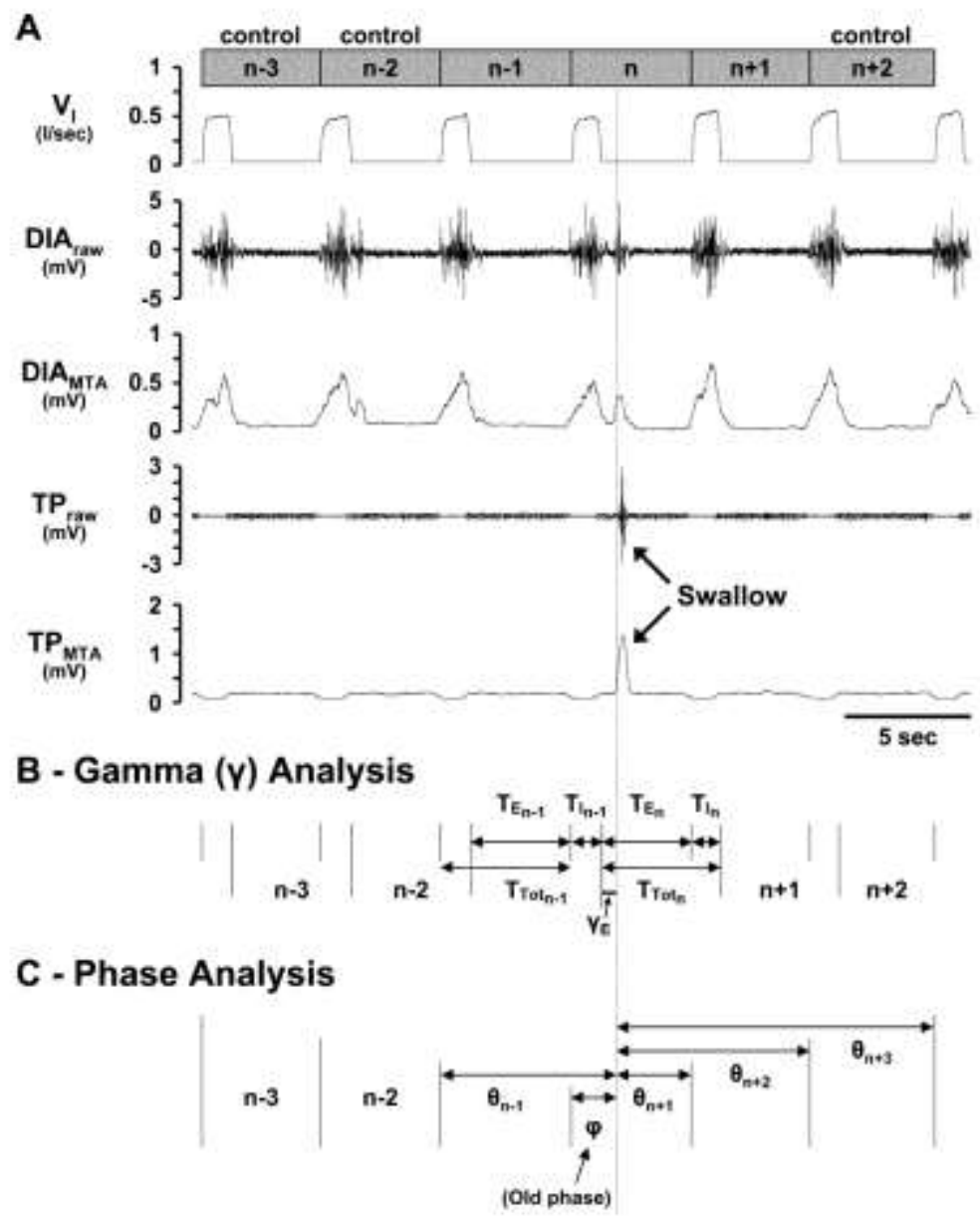

Figure 2. Depiction of swallow detection (Panel $A$ ) and derivation of variables for gamma (Panel B) and phase (Panel C) analyses. A) Swallows were considered solitary if the three breaths preceding $(n-1, n-2$, and $n-3)$ and the two breaths succeeding $(n+1$ and $n+2)$ the breath of the swallow (n) did not contain swallows. A breath was considered to begin with inspiration followed by expiration. The $n-3, n-2$, and $n+2$ breaths served as control breaths. The vertical line indicates the start of a swallow as evidenced by the raw and moving time average thyropharyngeus (TP) muscle signals. B) Gamma-expiratory ( $\mathrm{YE}$ ) and gamma-inspiratory ( $\mathrm{YI}$; not shown) were defined as the time from the beginning of the respective phase to the start of the swallow. Note that in the gamma analysis, the respiratory cycle was defined as an expiration followed by an inspiration. C) Old phase $(\varphi)$ was defined as the time from the start of the swallow to the beginning of the $\mathrm{n}$ breath. Cophases $(\theta)$ were defined as the time from the start of the swallow to the beginning of the preceding breath $(\theta n-1)$ and three succeeding breaths $(\theta n+1, \theta n+2$, and $\theta n+3)$. Values are normalized as a fraction of control breaths.

Two specific analyses were performed to examine the coordination of breathing and swallowing, a gamma $(Y)$ analysis and a phase analysis (Figs. 2B \& C). The $Y$ analysis investigated whether the time of occurrence of a swallow within the $I\left(Y_{I}\right)$ or $E\left(Y_{E}\right)$ phase, had

Respiratory Physiology \& Neurobiology, Vol 175, No. 2 (February 15, 2011): pg. 272-282. DOI. This article is (C) Elsevier and permission has been granted for this version to appear in e-Publications@Marquette. Elsevier does not grant permission for this article to be further copied/distributed or hosted elsewhere without the express permission from Elsevier. 
an effect on ventilatory parameters in the $n$ and/or $n-1$ breath. For the $\mathrm{Y}$ analysis, the respiratory cycle was defined as an $\mathrm{E}$ followed by an I. $\mathrm{Y}_{\mathrm{I}}$ was calculated as the time from the beginning of I to the start of the I swallow, expressed as a percent of the control $T_{I}$. $Y_{E}$ was calculated as the time from the beginning of $E$ to the start of the $E$ swallow (Fig. 2B), expressed as a percent of the control $T_{E} . T_{I}, T_{E}, T_{\text {Tot, }}$ $\mathrm{T}_{\mathrm{I}} / \mathrm{T}_{\mathrm{Tot}}, \mathrm{V}_{\mathrm{T}}$, and $\mathrm{V}_{\mathrm{T}} / \mathrm{T}_{\mathrm{I}}$ for the $n$ and $n-1$ breaths were then expressed as a percent of the control breaths and plotted against $Y_{I}$ or $Y_{E}$. $Y_{I}$ or $Y_{E}$ greater than 100 were possible when swallows occurred after the duration of the respective control $T_{I}$ or $T_{E}$ had been exceeded.

The phase analysis investigated whether swallows affected the respiratory rhythm generator. The old phase $(\varphi)$ was calculated as the time from the beginning of the $n$ breath to the start of the swallow (Fig. 2C). Cophases $(\theta)$ were calculated as the time from the beginning of the $n-1\left(\theta_{n-1}\right), n+1\left(\theta_{n+1}\right), n+2\left(\theta_{n+2}\right)$, and $n+3\left(\theta_{n+3}\right)$ breaths to the start of the swallow (Fig. 2C). $\varphi$ and $\theta$ were expressed as a ratio of the average $T_{\text {Tot }}$ of the control breaths. Solitary swallows were subdivided into 4 subtypes according to their time of occurrence within the respiratory cycle labeled as E, I, late-E, or early-I. Swallows that occurred during the $E$ phase with a $\theta_{n+1} / \varphi$ ratio $<0.35$ were classified as late-E, while those with a $\theta_{n+1} / \varphi$ ratio $>0.35$ were classified as $E$. Similarly, swallows that occurred during the I phase with a $\theta_{n+1} / \varphi$ ratio $>20$ were classified as early-I, while those with a $\theta_{n+1} / \varphi$ ratio $<20$ were classified as $\mathrm{I}$. We recognize that swallows that occurred during the I phase created a deglutition apnea, but these temporary pauses in airflow generally did not exceed the 0.3 s duration criteria necessary to trigger a newly defined $\mathrm{E}$ phase, and thus used an "I" nomenclature to swallows occurring during the I phase.

\subsection{Statistical analyses}

To determine if the occurrence of swallows significantly changed over time ( $51 / 2 \mathrm{hrs}$ ), or condition (control, 1 and $10 \mu \mathrm{l}$ IA injections), we used a two-way ANOVA with repeated measures and Tukey's post hoc analysis on the number of swallows per 30 minute bin as a percent of the control periods. Similarly, condition effects were determined with the same tests for: 1 ) the number of swallows occurring within the phases of the respiratory cycle (number of swallows per $10 \%$

Respiratory Physiology \& Neurobiology, Vol 175, No. 2 (February 15, 2011): pg. 272-282. DOI. This article is @ Elsevier and permission has been granted for this version to appear in e-Publications@ Marquette. Elsevier does not grant permission for this article to be further copied/distributed or hosted elsewhere without the express permission from Elsevier. 
respiratory phase bin), 2) the gamma analysis slope and $y$-intercept (comparing $n$ and $n-1$ breaths for all ventilatory variables), 3) when swallows occurred with respect to $\varphi$ (number of swallows per $10 \% \varphi$ bin), 4) the difference between cophases with respect to $\varphi$ (number of swallows per $10 \% \varphi$ bin), and 5 ) ventilatory variables with respect to $\varphi$ (ventilatory variables expressed as a percent of control breaths per $10 \% \varphi$ bin). A threshold for significance was set to $P<0.05$.

\subsection{Histological analyses}

Histological analyses have been reported previously (Bonis J.M. et al., 2010b) for these lesioned goats as well as for control goats. Briefly, all goats were euthanized (Beuthanasia, intravenously), and then the brain was perfused with physiological buffer solution (PBS) and fixed with $4 \%$ paraformaldehyde in PBS. The brain stem was excised and placed in 4\% paraformaldehyde in PBS for $24 \mathrm{~h}$, and then sequentially in 20 and $30 \%$ sucrose solutions. The brain stem was frozen and serially sectioned $(25 \mu \mathrm{m})$ from obex to the superior colliculi, and the sections were adhered to gelatin-chrome-alum-coated slides. Sections were acquired such that every fourth section was contained within a respective "series." Thus there were four series in total; within a series, each section was $100 \mu \mathrm{m}$ from the next section in sequence, allowing for high-resolution neuronal and anatomical profiling. The four series were stained for Nissl substance, muscarinic type-2 immunoreactivity, and stains unrelated to the purposes of this report. Single Nissl-stained tissue sections in the rostral pons were imaged every $200 \mu \mathrm{m}$ at $4 \times$ magnification utilizing a Nikon Eclipse E400 microscope after Kohler alignment, flat field subtraction and white-balance correction. About 20 image files per slide were then photomerged in Adobe Photoshop, calibrated, and analyzed after importation into MetaMorph Offline v. 7.1.3.0. The KFN, MPBN, and LPBN stain positive for M2 receptors (Mallios, V., 1995); thus, the count region for each was determined using the anti-M2 receptor antibody staining. The boundaries of these regions were then transferred to adjacent Nissl-stained sections for quantification made every $200 \mu \mathrm{m}$. The two laboratory staff members who completed the computer-assisted analyses were aware of the experimental treatment in the lesion groups, but they strictly adhered to the objective quantification outlined so as to not bias the results. Classic

Respiratory Physiology \& Neurobiology, Vol 175, No. 2 (February 15, 2011): pg. 272-282. DOI. This article is (C) Elsevier and permission has been granted for this version to appear in e-Publications@Marquette. Elsevier does not grant permission for this article to be further copied/distributed or hosted elsewhere without the express permission from Elsevier. 
stereological counting methods were not used in obtaining the cell counts. There was excellent agreement between the two staff members in results derived from a repeat analysis of identical images ( $<1 \%$ difference in total number of cells counted per section).

\section{Results}

\section{1 Histology}

In goats, the LPBN and MPBN course bilaterally through the middle and rostral pons flanked about the superior cerebellar peduncles, spanning $6-8 \mathrm{~mm}$ rostrocaudally (Fig. 3). The KFN spans 2$3 \mathrm{~mm}$ (Fig. 3) rostrocaudally at the ventrolateral aspect of the parabrachial complex, and is roughly spherical making it amenable to targeting via chronically implanted cannula and neurotoxic lesioning. Post-mortem histological analyses showed that in the lesioned goats, the deficit in neurons in the LPBN and MPBN tended to be most extensive in the more rostral regions while in the KFN, the greatest deficit was in the mid- range region (Fig. 3). In the lesioned goats, the average number of neurons was reduced $(P<0.05)$ to $52 \pm 12,51 \pm$ $16 \%$, and $51 \pm 20 \%$ of control goats in the LPBN, MPBN, and KFN respectively. Throughout all 3 subnuclei, the variation in number of neurons was similar in the lesioned and control goats (Fig. 3). We did not quantify neuron loss beyond the borders of the LPBN, MPBN, and $\mathrm{KFN}$, but from visual inspection, it was clear that the loss was less than in areas shown in Figure 3. In spite of variation among the goats in loss of neurons throughout the dorsolateral pons, the physiologic effects of the perturbations was uniform across all the goats as indicated by the small variance in most parameters altered by the perturbations.

Respiratory Physiology \& Neurobiology, Vol 175, No. 2 (February 15, 2011): pg. 272-282. DOI. This article is @ Elsevier and permission has been granted for this version to appear in e-Publications@Marquette. Elsevier does not grant permission for this article to be further copied/distributed or hosted elsewhere without the express permission from Elsevier. 
NOT THE PUBLISHED VERSION; this is the author's final, peer-reviewed manuscript. The published version may be accessed by following the link in the citation at the bottom of the page.
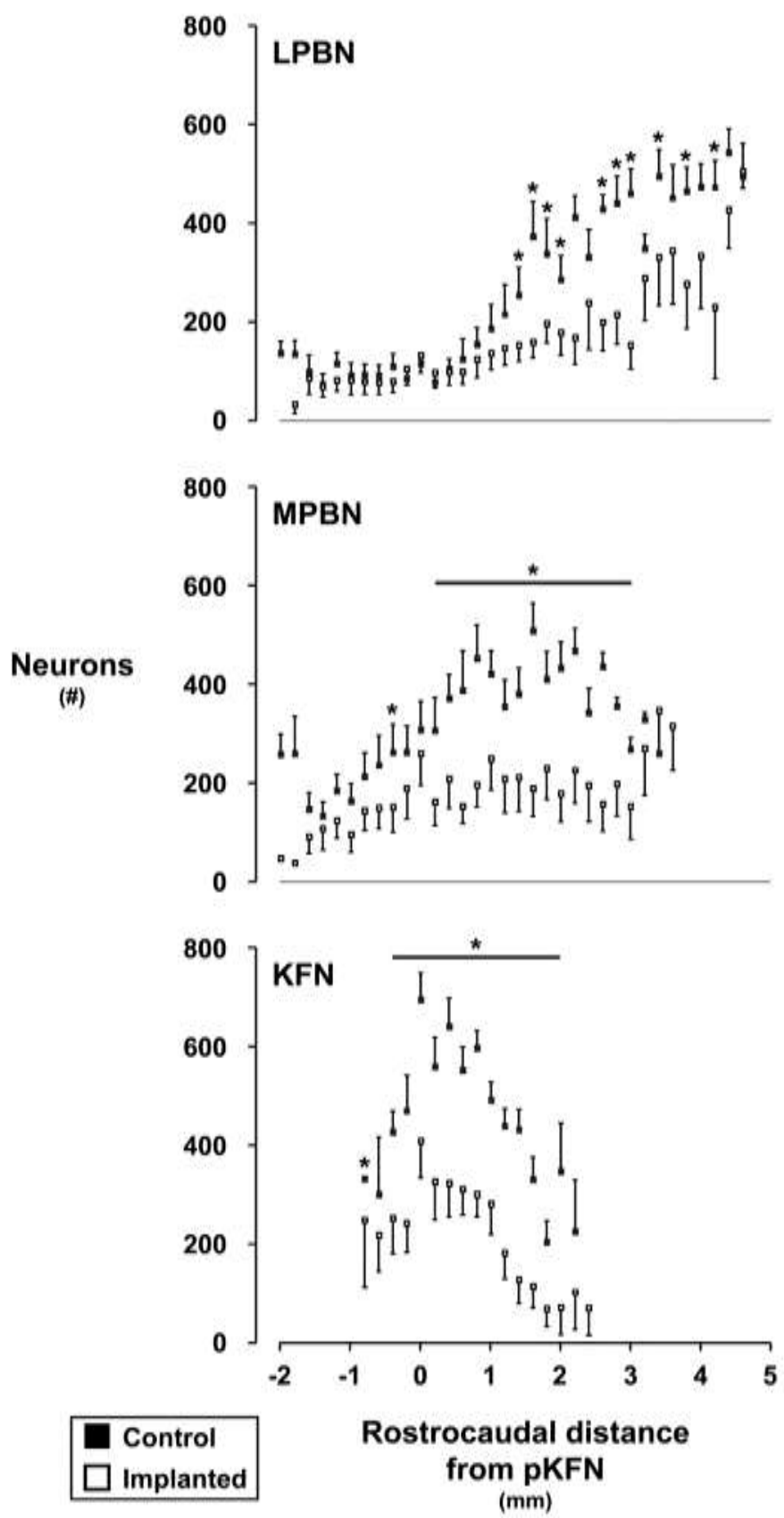

Figure 3. Number of neurons of control and lesioned goats in the LPBN, MPBN, and KFN caudal and rostral to the peak number of neurons in the KFN (pKFN). Neuron counts were made on single tissue sections at $200 \mathrm{~m}$ intervals. The horizontal lines and asterisks indicate where neuron counts were significantly $(P<0.05)$ reduced in the lesioned goats compared to controls.

Respiratory Physiology \& Neurobiology, Vol 175, No. 2 (February 15, 2011): pg. 272-282. DOI. This article is (C) Elsevier and permission has been granted for this version to appear in e-Publications@Marquette. Elsevier does not grant permission for this article to be further copied/distributed or hosted elsewhere without the express permission from Elsevier. 
NOT THE PUBLISHED VERSION; this is the author's final, peer-reviewed manuscript. The published version may be accessed by following the link in the citation at the bottom of the page.

\subsection{Spontaneous, solitary swallows}

The sequential motor activation pattern of the 4 airway muscles was consistent throughout the $51 / 2 \mathrm{hr}$ studies (Fig. 1). Moreover, the duration of motor activity of individual muscles was consistent and did not significantly change $(P>0.05)$ throughout all studies. For example, the duration of PCA activity was $0.254,0.261,0.269$, and 0.258 during control conditions and during 15 minute intervals 30 , 120 , and 180 minutes respectively after the first $10 \mu$ injection of IA. The breath-to-breath coefficients of variation in duration of muscle activity were $7.9 \pm 2.1,7.5 \pm 2.1,7.9 \pm 1.5$, and $8.2 \pm 0.9 \%$ for the 4 intervals. These consistent motor patterns suggest that the IA injections did not elicit dysphagic swallows. However, since our PCA EMG recordings did not permit quantifying the magnitude of the swallow-related burst in activity, we can not eliminate the possibility that IA injections induced dysphagic swallows.

Within the 52,935 breaths analyzed, there were 10,928 spontaneous swallows and of these, 5,705 (52\% of total swallows) were solitary and met additional selection criteria for inclusion (see Methods). Expiratory ( $E$ ), inspiratory (I), late-E, and early-I swallows accounted for $2.5 \%$ (144), 24.7\% (1411), 67.6\% (3855), and 5.2\% (295) of solitary swallows, respectively.

\subsection{Effects of ibotenic acid injections on swallowing}

During the control study, the occurrence of swallows was constant over the $51 / 2 \mathrm{hr}$ time period (Fig. 4) at a rate of approximately 1.5 swallows per minute ( $10 \%$ of breaths contained a solitary swallow). Over the course of the $51 / 2$ hour injection protocol, the $1 \mu \mathrm{l}$ volume had no significant $(P>0.10)$ effect on the occurrence of swallows. However, the first $10 \mu$ IA injection elicited an increase ( $P<$ 0.05 ) in swallows to $65 \%$ above control levels 60 to 90 minutes after injection which was not accentuated by the contralateral injection. The increase was followed by a significant attenuation $(P<0.05)$ of swallows relative to the increase but not significantly $(P>0.05)$ lower than control (Fig. 4). The swallowing response to IA injection into the dorsolateral pons was similar to the ventilatory response reported previously (Bonis J.M. et al., 2010b).

Respiratory Physiology \& Neurobiology, Vol 175, No. 2 (February 15, 2011): pg. 272-282. DOI. This article is @ Elsevier and permission has been granted for this version to appear in e-Publications@Marquette. Elsevier does not grant permission for this article to be further copied/distributed or hosted elsewhere without the express permission from Elsevier. 


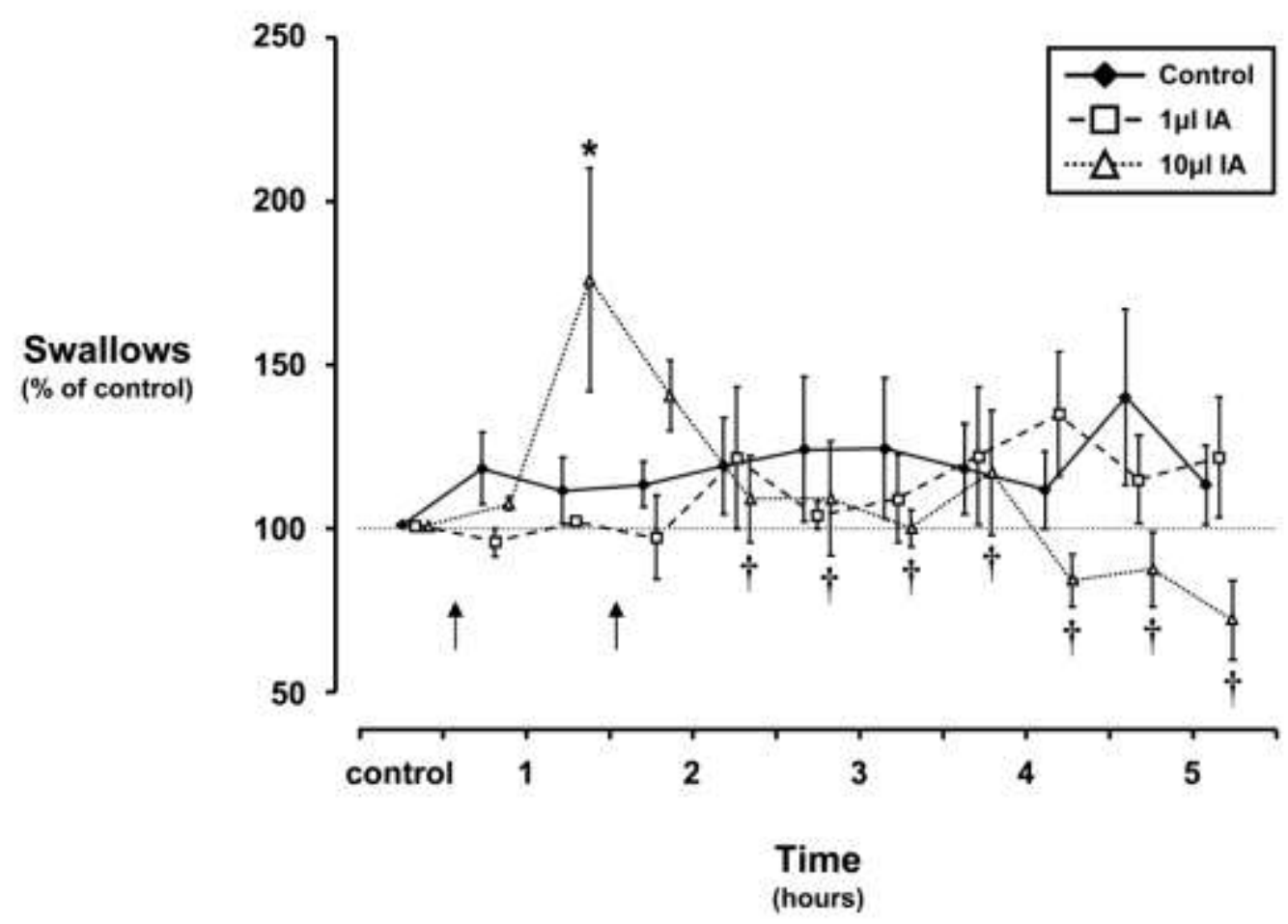

Figure 4. Frequency of swallows over $51 / 2$ hours of a control study and over 5 hours after injecting 1 and $10 \mu$ ibotenic acid (IA) bilaterally into the dorsolateral pons. Note that during control studies and with injection of $1 \mu \mathrm{IA}$, the occurrence of swallows did not significantly differ from control levels. Within 60 to 90 minutes after injection (arrows indicate times of ipsilateral and contralateral injections, respectively) of $10 \mu \mathrm{I}$ IA into the pons of awake goats, the occurrence of swallows was significantly (asterisk, $\mathrm{P}<0.05$ ) increased $65 \%$ above levels seen during the control study at the same time point. Following this increase, the occurrence of swallows was significantly (daggers, $\mathrm{P}<0.05$ ) attenuated relative to the initial transient increase. Data plotted as a percent of control levels $\pm \mathrm{SE}$.

The occurrence of swallows within different phases of the respiratory cycle is shown in Figure 5 . The vast majority of spontaneous swallows in the pre-lesion control studies showed a peak occurrence between $80-90 \%$ of the $\mathrm{E}$ phase (late $\mathrm{E}$ or the E-I transition), where these late-E swallows were E-terminating swallows. This general pattern of occurrence of swallows continued after bilateral 1 and $10 \mu \mathrm{l}$ IA injections. The $10 \mu \mathrm{l}$, but not the $1 \mu \mathrm{l}$ IA injections increased $(P<0.05)$ the occurrence of swallows between $90-100 \%$ of the $E$ phase, with average occurrence 82 swallows more $(P<0.05)$ than during the control study (Fig. 5). However, there was no significant difference in the total number of swallows among all the studies.

Respiratory Physiology \& Neurobiology, Vol 175, No. 2 (February 15, 2011): pg. 272-282. DOI. This article is (C) Elsevier and permission has been granted for this version to appear in e-Publications@Marquette. Elsevier does not grant permission for this article to be further copied/distributed or hosted elsewhere without the express permission from Elsevier. 


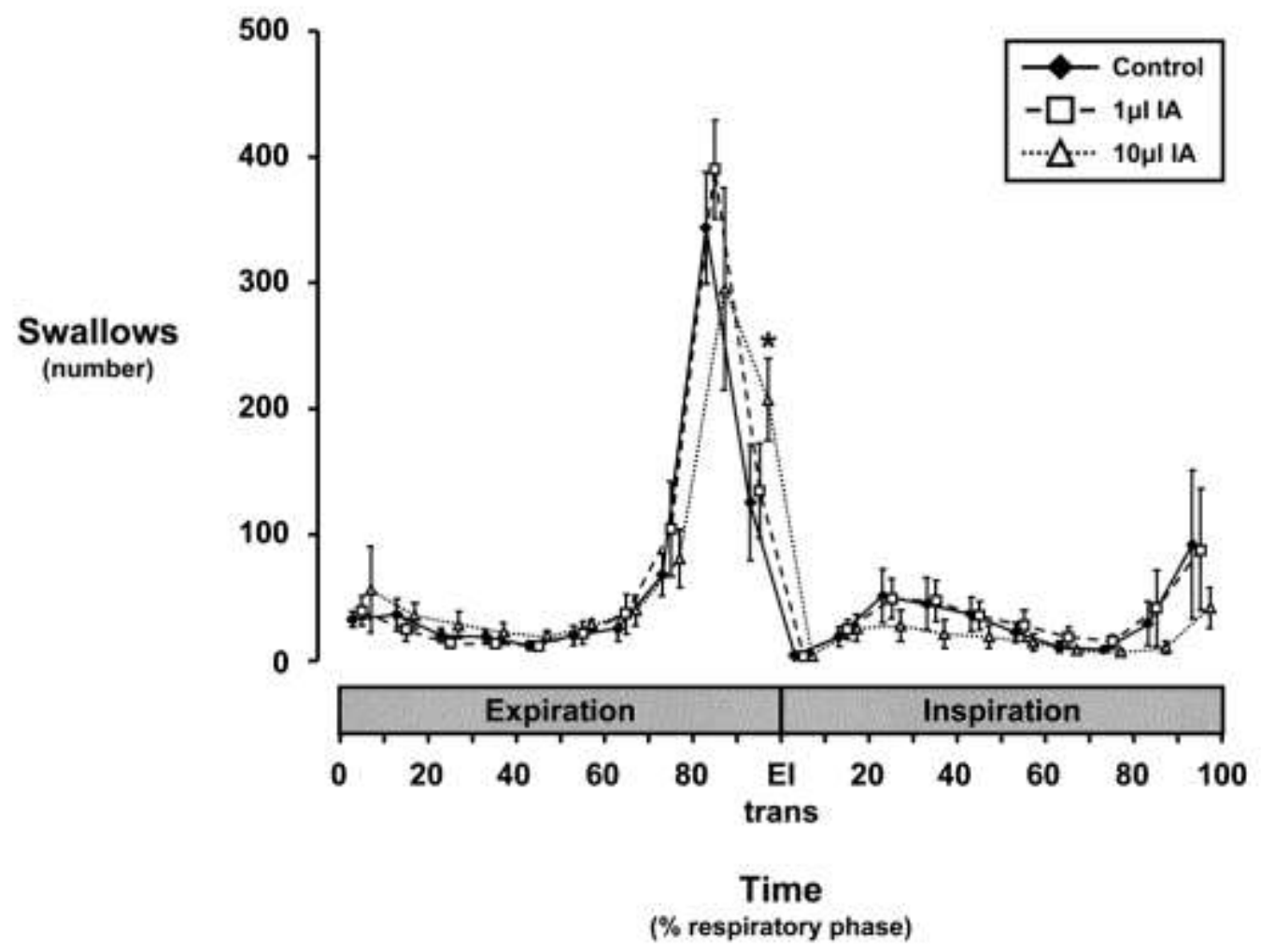

Figure 5. Histogram of swallow occurrence within respiratory expiratory (E) and inspiratory (I) phases during control and ibotenic acid injection protocols. Note that: a) injection of $10 \mu \mathrm{l}$ IA into the dorsolateral pons of awake goats significantly (asterisk, $\mathrm{P}$ $<0.05$ ) increased the number of swallows between 90 and $100 \%$ of $E$ compared to the control study within the same $10 \%$ bin, b) regardless of study conditions, the occurrence of swallows tended to increase throughout $E$, while the occurrence of swallows during I was more evenly distributed, c) the pattern of occurrence of swallows was well conserved irrespective of study conditions, and d) the majority of swallows occur late in E and are thus E-terminating swallows.

\subsection{Within-breath effects of swallows on breathing: a gamma $(y)$ analysis}

A gamma analysis was performed for swallows occurring during I or $E$ to determine whether the time of occurrence of a swallow during the respiratory cycle had differential effects on the characteristics of the breath in which a swallow occurred $(n)$ or the breath preceding the swallow $(n-1)$, and subsequently whether injection of IA altered these characteristics. Figure 6 illustrates one example from the $\gamma_{E}$ analysis, plotting the effect of time of occurrence of $E$ swallows versus expiratory time $\left(T_{E}\right)$. The gamma analysis yields two variables, slope and $y$-intercept, which describe the relationship of the time of 
occurrence within the $\mathrm{E}$ phase with the $\mathrm{T}_{\mathrm{E}}$ of the $n$ and $n-1$ breaths (Fig. 6). For the $n-1$ breath, the slope and $y$-intercept is 0.04 and 0.97 , respectively, consistent with the concept that the swallow in the $n$ breath had no effect on $\mathrm{T}_{\mathrm{E}}$ in the $n-1$ breath (Fig. 6). The slope $(0.8431)$ of the $Y_{E}$ VS. TE relationship was increased and the $y$-intercept $(0.273)$ was decreased for $n$ breaths relative to $n-1$, consistent with most swallows being E-terminating (Fig. 6). In other words, swallows occurring early in $E$ relative to control predictably have a small $T_{E}$, while swallows occurring late in $E$ relative to control have a large $T_{E}$, neither of which significantly affects the $n-1$ breath.

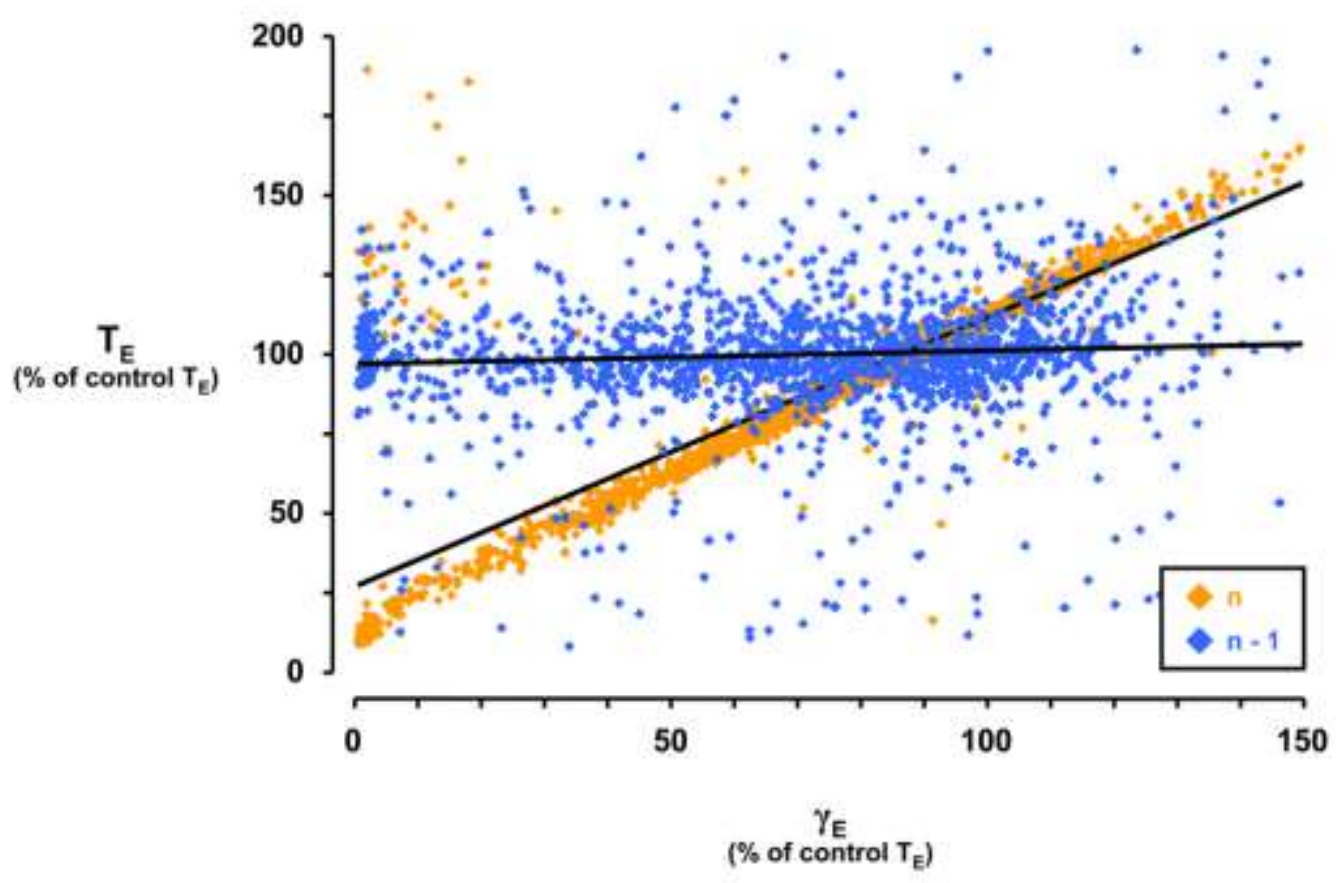

Figure 6. Depiction of gamma-expiratory $(\gamma E)$ analysis for $n$ and $n-1$ breaths during the control study. During the control study, the slope of the gamma-expiratory $(\mathrm{VE})$ versus expiratory time (TE) relationship was greater for $\mathrm{n}$ breaths compared to $n-1$ breaths. The $y$-intercept of the trendline for $n$ breaths was decreased versus the $\mathrm{y}$-intercept of the trendline for $\mathrm{n}-1$ breaths. The linear regression for $\mathrm{n}$ breaths is $\mathrm{y}=$ $0.8431 x+0.273$ and for $n-1$ breaths is $y=0.0419 x+0.9699$. Note that the majority of expiratory (E) swallows terminate $E$, and thus occur late in the respiratory phase (see Figure 4). Therefore, E-terminating swallows largely dictate the effect shown for $T E$, i.e. swallows occurring early in $E$ have a small TE while swallows occurring late in E have a large TE. YE values greater than 100 are possible because some expirations containing swallows are longer than those of the control breaths.

In the $\gamma_{E}$ analysis for the control study, the slope from $n-1$ to $n$ breaths increased $(P<0.05)$ for the $T_{I}, T_{E}$, and $T_{T o t} V S . Y_{E}$ relationship, 
and decreased $(P<0.05)$ for the $T_{I} / T_{\text {Tot }}$ VS. $Y_{E}$ relationship (Table 1 ). The $y$-intercept from $n-1$ to $n$ breaths decreased $(P<0.05)$ for the $T_{I}$,

$T_{E}, T_{T o t}$, and $V_{T}$ VS. $Y_{E}$ relationship, and increased $(P<0.05)$ for the $\mathrm{T}_{\mathrm{I}} / \mathrm{T}_{\text {Tot }} \mathrm{VS}$. $\mathrm{Y}_{\mathrm{E}}$ relationship (Table 1 ). Physiologically, this indicates that for swallows occurring progressively later in $E_{,} T_{E}$ and $T_{I}$ for the $n$ breath were proportionately lengthened to accommodate the swallow. The increase in slope from $n-1$ to $n$ breaths for the $T_{I}$ VS. $Y_{E}$ relationship was attenuated $(P<0.05)$ with the $10 \mu$ IA injection (Table 1$)$. This $T_{I}$ effect also resulted in a more negative $(P<0.05)$ slope and a more positive $(P<0.05)$ y-intercept from $n-1$ to $n$ breaths for the $\mathrm{T}_{\mathrm{I}} / \mathrm{T}_{\text {Tot }} \mathrm{VS}$. $\mathrm{Y}_{\mathrm{E}}$ relationship compared to control conditions. Physiologically, this indicates that with KFN perturbation via $10 \mu$ IA injection, the usually requisite lengthening of $n$ breath $T_{E}$ and $T_{I}$ to accommodate $E$ swallows is attenuated, such that ventilatory output may be reduced or temporarily insufficient. Injection of $1 \mu$ IA increased $(P<0.05)$ the slope from $n-1$ to $n$ breaths for the $\mathrm{V}_{\mathrm{T}} \mathrm{VS} . \mathrm{V}_{\mathrm{E}}$ relationship (Table 1 ). Injection of 1 or $10 \mu$ IA attenuated or even reversed $(P<0.05)$ the increase in the $y$-intercept from $n-1$ to $n$ breaths for the $\mathrm{V}_{\mathrm{T}} / \mathrm{T}_{\mathrm{I}}$ vS. $\mathrm{V}_{\mathrm{E}}$ relationship (Table 1 ).

\section{Table 1}

\begin{tabular}{|c|c|c|c|c|c|c|c|c|c|c|c|c|}
\hline & \multicolumn{12}{|c|}{ Gamma-Expiratory } \\
\hline & \multicolumn{6}{|c|}{ Slope } & \multicolumn{6}{|c|}{ Y-intercept } \\
\hline & \multicolumn{2}{|c|}{ Control } & \multicolumn{2}{|c|}{ 1 $\boldsymbol{\mu l}$ IA } & \multicolumn{2}{|c|}{ 10HI IA } & \multicolumn{2}{|c|}{ Control } & \multicolumn{2}{|c|}{$1 \boldsymbol{\mu l}$ IA } & \multicolumn{2}{|c|}{$10 \mu \mathrm{l}$ IA } \\
\hline & $n-1$ & $\mathbf{n}$ & $n-1$ & $\mathbf{n}$ & n-1 & $\mathbf{n}$ & n-1 & $\mathbf{n}$ & $\mathbf{n}-\mathbf{1}$ & $\mathbf{n}$ & $\mathbf{n}-\mathbf{1}$ & $\mathbf{n}$ \\
\hline $\mathbf{T}_{\mathbf{I}}$ & $\begin{array}{c}0.11 \\
(0.06)\end{array}$ & $\begin{array}{l}* 0.20 \\
(0.05)\end{array}$ & $\begin{array}{c}0.14 \\
(0.07)\end{array}$ & $\begin{array}{l}* 0.29 \\
(0.02)\end{array}$ & $\begin{array}{c}0.16 \\
(0.09)\end{array}$ & $\begin{array}{c}0.23 \\
(0.07)\end{array}$ & $\begin{array}{c}0.93 \\
(0.07)\end{array}$ & $\begin{array}{l}* 0.66 \\
(0.02)\end{array}$ & $\begin{array}{c}0.89 \\
(0.07)\end{array}$ & $\begin{array}{l}* 0.61 \\
(0.04)\end{array}$ & $\begin{array}{c}0.86 \\
(0.08)\end{array}$ & $\begin{array}{l}* 0.71 \\
(0.05)\end{array}$ \\
\hline $\mathbf{T}_{\mathbf{E}}$ & $\begin{array}{c}0.05 \\
(0.01)\end{array}$ & $\begin{array}{l}* 0.81 \\
(0.06)\end{array}$ & $\begin{array}{c}0.07 \\
(0.02)\end{array}$ & $\begin{array}{l}* 0.90 \\
(0.03)\end{array}$ & $\begin{array}{c}0.03 \\
(0.02)\end{array}$ & $\begin{array}{l}* 0.88 \\
(0.06)\end{array}$ & $\begin{array}{c}0.97 \\
(0.01)\end{array}$ & $\begin{array}{l}* 0.29 \\
(0.06)\end{array}$ & $\begin{array}{c}0.96 \\
(0.02)\end{array}$ & $\begin{array}{l}* 0.23 \\
(0.05)\end{array}$ & $\begin{array}{c}0.95 \\
(0.02)\end{array}$ & $\begin{array}{l}* 0.21 \\
(0.06)\end{array}$ \\
\hline $\mathbf{T}_{\text {Tot }}$ & $\begin{array}{c}0.07 \\
(0.02)\end{array}$ & $\begin{array}{l}* 0.63 \\
(0.06)\end{array}$ & $\begin{array}{c}0.09 \\
(0.01)\end{array}$ & $\begin{array}{l}* 0.71 \\
(0.02)\end{array}$ & $\begin{array}{c}0.08 \\
(0.02)\end{array}$ & $\begin{array}{l}* 0.68 \\
(0.05)\end{array}$ & $\begin{array}{c}0.95 \\
(0.02)\end{array}$ & $\begin{array}{l}* 0.40 \\
(0.05)\end{array}$ & $\begin{array}{c}0.94 \\
(0.02)\end{array}$ & $\begin{array}{l}* 0.35 \\
(0.04)\end{array}$ & $\begin{array}{c}0.92 \\
(0.03)\end{array}$ & $\begin{array}{l}* 0.35 \\
(0.04)\end{array}$ \\
\hline $\mathbf{T}_{\mathrm{I}} / \mathbf{T}_{\text {Tot }}$ & $\begin{array}{c}0.06 \\
(0.06)\end{array}$ & $\begin{array}{c}* \\
-0.68 \\
(0.13)\end{array}$ & $\begin{array}{c}0.07 \\
(0.08)\end{array}$ & $\begin{array}{c}* \\
-0.78 \\
(0.12)\end{array}$ & $\begin{array}{c}0.15 \\
(0.10)\end{array}$ & $\begin{array}{c}+*-0.96 \\
(0.15)\end{array}$ & $\begin{array}{c}0.97 \\
(0.05)\end{array}$ & $\begin{array}{l}* 1.50 \\
(0.14)\end{array}$ & $\begin{array}{c}0.95 \\
(0.07)\end{array}$ & $\begin{array}{l}* 1.60 \\
(0.11)\end{array}$ & $\begin{array}{c}0.92 \\
(0.08)\end{array}$ & $\begin{array}{c}+* 1.81 \\
(0.12)\end{array}$ \\
\hline $\mathbf{V}_{\mathbf{T}}$ & $\begin{array}{c}0.18 \\
(0.06)\end{array}$ & $\begin{array}{c}0.22 \\
(0.07)\end{array}$ & $\begin{array}{c}0.21 \\
(0.09)\end{array}$ & $\begin{array}{l}* 0.34 \\
(0.01)\end{array}$ & $\begin{array}{c}0.21 \\
(0.11)\end{array}$ & $\begin{array}{c}0.32 \\
(0.10)\end{array}$ & $\begin{array}{c}0.85 \\
(0.06)\end{array}$ & $\begin{array}{l}* 0.66 \\
(0.05)\end{array}$ & $\begin{array}{c}0.82 \\
(0.08)\end{array}$ & $\begin{array}{l}* 0.58 \\
(0.02)\end{array}$ & $\begin{array}{c}0.83 \\
(0.10)\end{array}$ & $\begin{array}{l}* 0.61 \\
(0.07)\end{array}$ \\
\hline $\mathbf{V}_{\mathbf{T}} / \mathbf{T}_{\mathbf{I}}$ & $\begin{array}{c}0.10 \\
(0.02)\end{array}$ & $\begin{array}{c}0.06 \\
(0.05)\end{array}$ & $\begin{array}{c}0.11 \\
(0.03)\end{array}$ & $\begin{array}{c}0.08 \\
(0.04)\end{array}$ & $\begin{array}{c}0.08 \\
(0.05)\end{array}$ & $\begin{array}{c}0.14 \\
(0.06)\end{array}$ & $\begin{array}{c}0.90 \\
(0.01)\end{array}$ & $\begin{array}{l}* 0.97 \\
(0.07) \\
\end{array}$ & $\begin{array}{c}0.89 \\
(0.03)\end{array}$ & $\begin{array}{c}0.95 \\
(0.06) \\
\end{array}$ & $\begin{array}{c}0.93 \\
(0.05)\end{array}$ & $\begin{array}{l}+0.86 \\
(0.07)\end{array}$ \\
\hline
\end{tabular}

Expiratory gamma analysis. Asterisks denote significant $(P<0.05)$ difference of $n$ breath from $n-1$ breath. Daggers denote significant $(P<0.05)$ difference from respective control value. Shaded cells indicate departures from control study trends due to injection of 1 and/or $10 \mu$ l of ibotenic acid (IA). TI, inspiratory time; TE, expiratory time; TTot, total respiratory cycle time; TI/TTot, inspiratory drive; VT, tidal volume; VT/TI, volume per inspiration.

Respiratory Physiology \& Neurobiology, Vol 175, No. 2 (February 15, 2011): pg. 272-282. DOI. This article is (C) Elsevier and permission has been granted for this version to appear in e-Publications@Marquette. Elsevier does not grant permission for this article to be further copied/distributed or hosted elsewhere without the express permission from Elsevier. 
NOT THE PUBLISHED VERSION; this is the author's final, peer-reviewed manuscript. The published version may be accessed by following the link in the citation at the bottom of the page.

The gamma analysis of inspiration $\left(\mathrm{Y}_{\mathrm{I}}\right)$ yielded few significant effects, where there were no effects of I swallows on the slopes, but the $y$-intercept from $n-1$ to $n$ breaths decreased $(P<0.05)$ for the $V_{T} / T_{I}$ vs. $Y_{I}$ relationship (data not shown). There were no significant effects of IA injection in the $\gamma_{I}$ analysis (data not shown).

\subsection{Respiratory rhythm: a phase analysis}

To determine whether swallows affected the respiratory rhythm and subsequently whether injection of IA altered these effects, a phase analysis (see Fig. 2C) was performed. While the histogram in Figure 5 emphasizes the importance of the timing of swallows within a particular phase ( $E$ or I) of the respiratory cycle, Figure 7 emphasizes the importance of the timing of swallows within the respiratory cycle ( $\left.T_{\text {Tot }}\right)$ relative to control breaths $(n-3, n-2$, and $n+2)$. In other words, Figure 5 bins swallows based on occurrence within a particular phase ( $E$ or I) but doesn't take into consideration that the $n$ breath has been lengthened by the occurrence of the swallow, while Figure 7 bins swallows based on occurrence within a control respiratory cycle ( $\left.\mathrm{T}_{\text {Tot }}\right)$ to account for the effects on respiratory rhythm, irrespective of when the swallow occurred during that phase (E or I).

Respiratory Physiology \& Neurobiology, Vol 175, No. 2 (February 15, 2011): pg. 272-282. DOI. This article is (C) Elsevier and permission has been granted for this version to appear in e-Publications@ Marquette. Elsevier does not grant permission for this article to be further copied/distributed or hosted elsewhere without the express permission from Elsevier. 


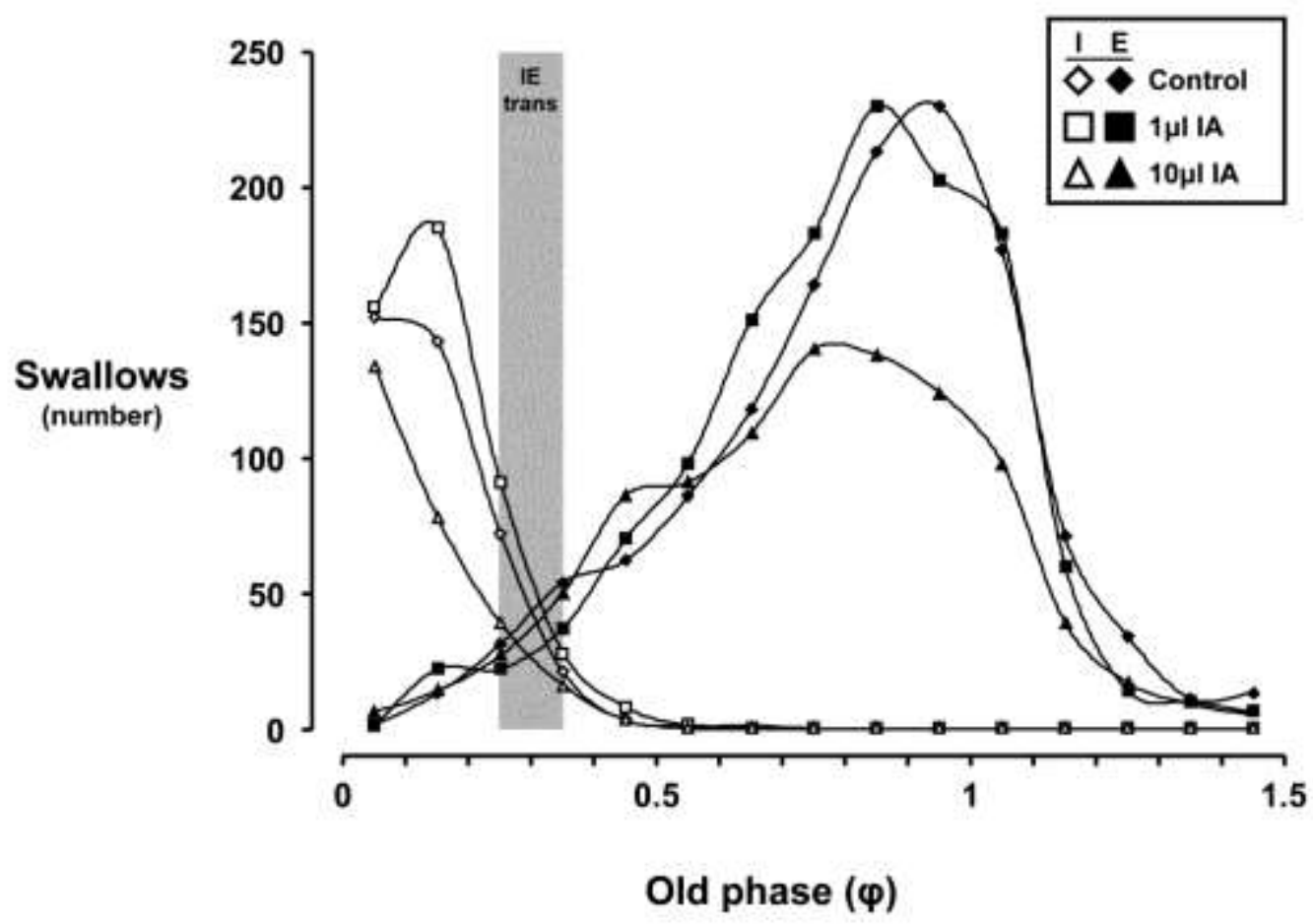

Figure 7. Histogram of swallow occurrence within the respiratory cycle during control and ibotenic acid injection protocols. The number of swallows in the $10 \mu$ l ibotenic acid (IA) studies was significantly $(P<0.001)$ less than during the control and $1 \mu$ IA studies. The phase transition between inspiration and expiration (IE trans; denoted by grey bar) is between an old phase $(\varphi)$ of 0.25 to 0.35 for all study conditions. Note that the pattern of occurrence of swallows is relatively well preserved across $\varphi$, and that the peak in expiratory swallows is near an $\varphi$ of 1 . Open symbols indicate inspiratory (I) swallows, while closed symbols indicate expiratory (E) swallows. $\varphi$ values greater than 1 are possible because some respiratory cycles are longer than the total respiratory cycle time (TTot) of control breaths, some presumably due to the effects of swallowing on respiratory timing parameters (See Figure 11).

Figure 7 illustrates the relationship of I or E swallows vs. old phase $(\varphi)$, or the representative $\mathrm{T}_{\text {Tot }}$. For all study conditions, the phase transition from I to E swallows occurred between an $\varphi$ of 0.25 to 0.35 (Fig. 7). The pattern of occurrence of swallows is well preserved across $\varphi$, with peak E swallow occurrence at a $\varphi$ of 1 (Fig. 7). However, injection of $10 \mu$ IA decreased $(P<0.05)$ the overall number of solitary swallows compared to control and $1 \mu$ IA studies (Fig. 7) with respect to $\varphi$.

Respiratory Physiology \& Neurobiology, Vol 175, No. 2 (February 15, 2011): pg. 272-282. DOI. This article is @ Elsevier and permission has been granted for this version to appear in e-Publications@Marquette. Elsevier does not grant permission for this article to be further copied/distributed or hosted elsewhere without the express permission from Elsevier. 
NOT THE PUBLISHED VERSION; this is the author's final, peer-reviewed manuscript. The published version may be accessed by following the link in the citation at the bottom of the page.

Hypothetically, if swallows did not affect the respiratory rhythm in the breaths preceding and following the swallow, then a plot of cophases $(\theta)$ vs. $\varphi$ would resemble Figure $8 \mathrm{~A}$ - a series of parallel lines with a slope of -1 and an amplitude difference of $\theta=1$.

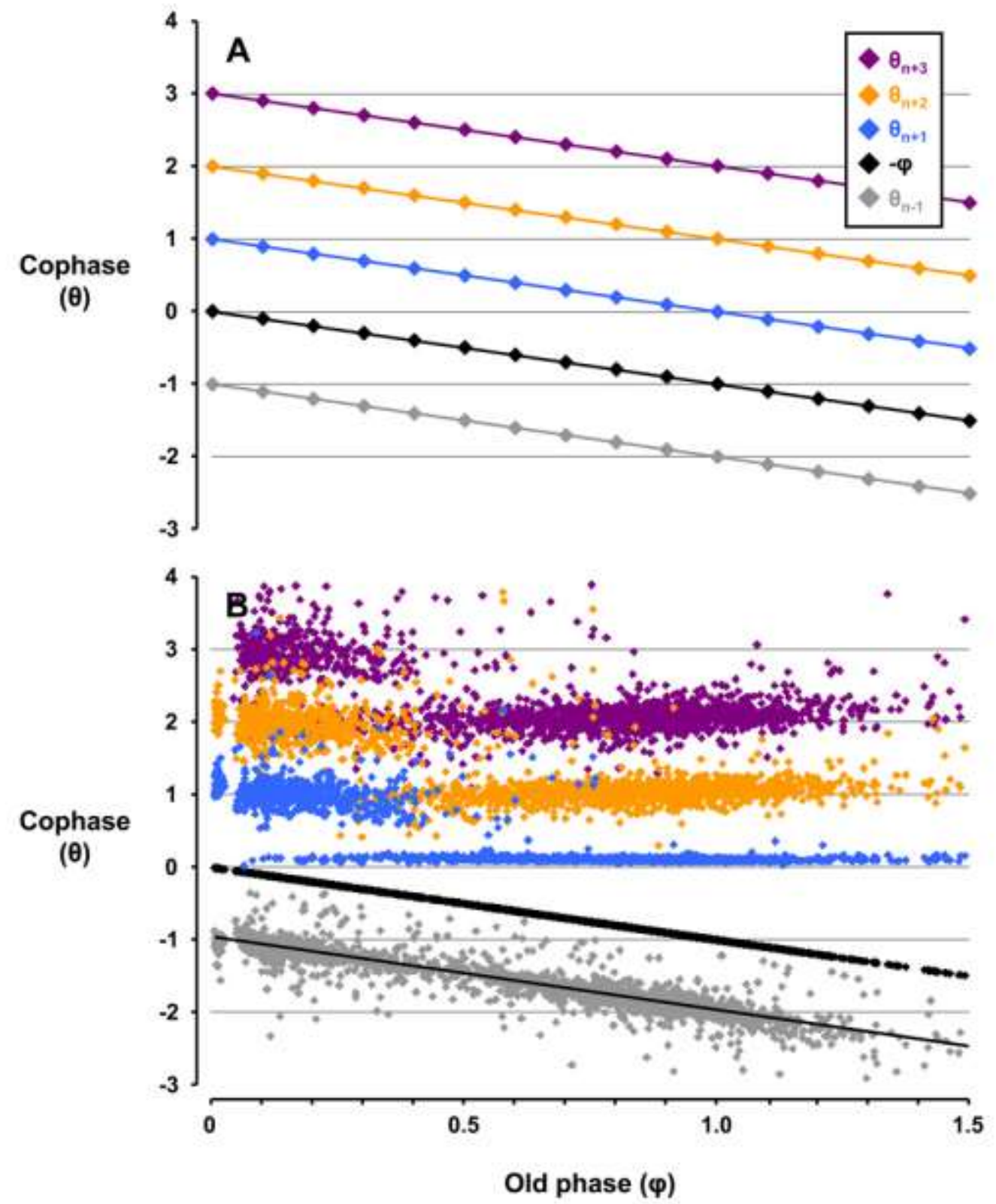

Figure 8. Depiction of the phase analysis of an idealized example (Panel $A$ ) and data during the control study (Panel B). In Panel A, the idealized plot of $\theta$ n versus $\varphi$ depicts swallows having no effect on respiratory rhythm indicated by the respective points organizing into series of parallel lines with a slope of -1 and an amplitude

Respiratory Physiology \& Neurobiology, Vol 175, No. 2 (February 15, 2011): pg. 272-282. DOI. This article is @ Elsevier and permission has been granted for this version to appear in e-Publications@Marquette. Elsevier does not grant permission for this article to be further copied/distributed or hosted elsewhere without the express permission from Elsevier. 
NOT THE PUBLISHED VERSION; this is the author's final, peer-reviewed manuscript. The published version may be accessed by following the link in the citation at the bottom of the page.

difference where $\theta=1$. Thus, respiratory rhythm was not reset. In Panel $B$, during the control study the pattern of $n+1$ breaths deviated from that in Panel $A$ and persisted through subsequent breaths $(n+2$ and $n+3)$. Thus, swallows reset respiratory rhythm, with amplitude changes where $\theta<1$ indicating phase advances and $\theta>1$ indicating phase delays. The linear regression for $\theta n-1$ is $y=-1.0088 \times-0.9915$, confirming no anticipation of the phase shift prior to swallows.

Deviation below or above these parallel lines indicate a phase advance or delay, respectively, and the resetting of respiratory rhythm. During the control study in Figure 8B, the $\theta_{n-1}$ series $(y=$ $-1.0088 \times-0.9915$; red data points) closely approximates the idealized $\theta_{n-1}$ series in Figure $8 A(y=-1 \times-1)$, establishing that there was no respiratory phase shifting prior to swallows, or "anticipation" of the occurrence of a swallow. In contrast, the $\theta_{n+1}$ series in Figure 8B deviated from that in Figure 8A, indicating marked phase shifting in the breath following swallows. Furthermore, this phase shifting continued through the $\theta_{n+2}$ and $\theta_{n+3}$ series, suggesting the phase shifting in the $\theta_{n+1}$ series was not a transient rhythmic perturbation, but rather a persistent and complete resetting of the respiratory rhythm following a swallow.

The relationship among $\varphi$ and $\theta_{n+1}$ (and other subsequent breaths) appears to be nonlinear, with the data apparently "clustering" in different groups. To gain further insight into this relationship, we separated the swallows based on their occurrence within the respiratory cycle. After this separation, it became apparent that any phase shifting by early-I and late-E swallows had a predictable and consistent effect on $\theta$. Early-I swallows largely did not effect the respiratory rhythm, while late-E swallows with a $\varphi<1$ caused phase advancing (below idealized line), at a $\varphi=1$ did not effect phase, and at a $\varphi>1$ caused phase delay (above idealized line; Fig. 9). When considering only I and $E$ swallows, a linear regression analysis ( $y=$ $0.0336 x+0.9798$ ) suggested that during the control study, there was a near zero slope (0.0336) and y-intercept near 1 (0.9798) indicative of complete resetting of respiratory rhythm. In contrast, bilateral injections of IA into the KFN of awake goats attenuated respiratory rhythm resetting by $I$ and $E$ swallows, as evidenced by the slope of the linear regressions for the $1 \mu \mathrm{l}(\mathrm{y}=-0.2024 x+1.0049)$ and $10 \mu \mathrm{l}(\mathrm{y}=$ $-0.6493 x+1.0133)$ IA injections. In other words, the effects of

Respiratory Physiology \& Neurobiology, Vol 175, No. 2 (February 15, 2011): pg. 272-282. DOI. This article is @ Elsevier and permission has been granted for this version to appear in e-Publications@ Marquette. Elsevier does not grant permission for this article to be further copied/distributed or hosted elsewhere without the express permission from Elsevier. 
increasing volumes of neurotoxin injections altered the relationship between swallowing and the resetting of respiratory rhythm, more closely aligning with the idealized $\theta_{n+1}$ series $(y=-1 x+1)$ in Figure $8 \mathrm{~A}$.

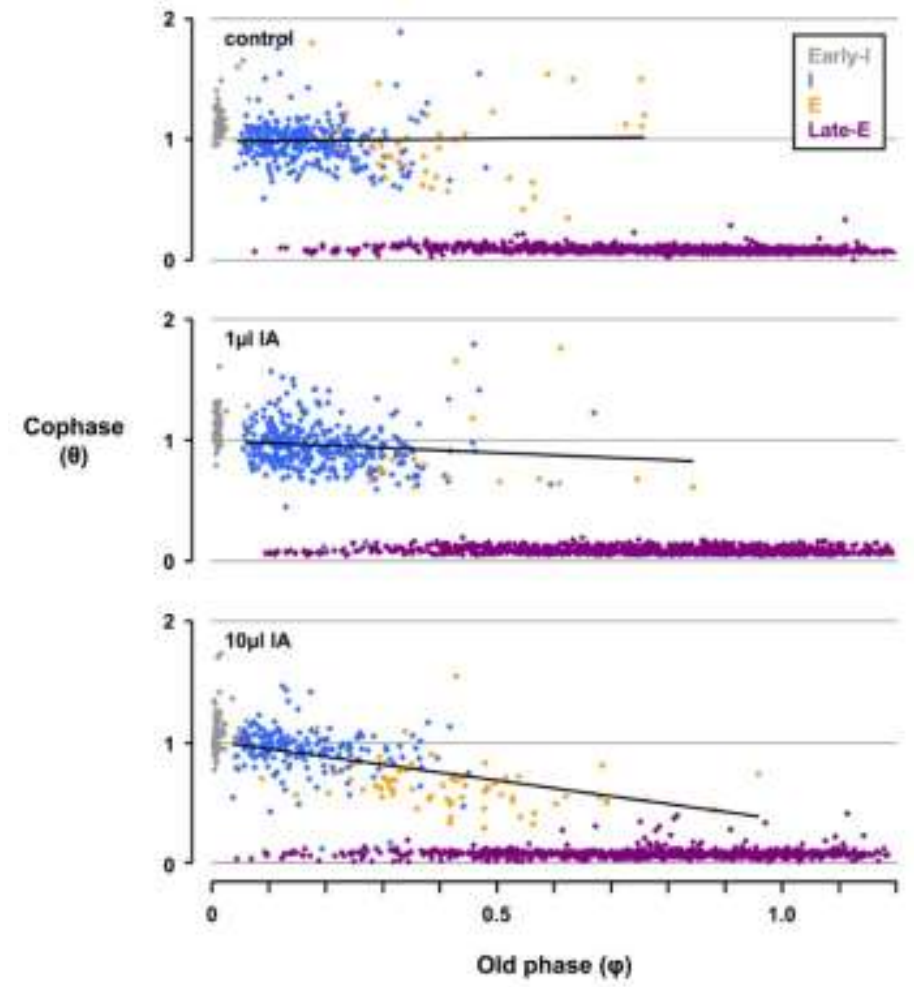

Figure 9. The phase analysis for $n+1$ breaths for the control study and for studies after 1 and $10 \mu l$ injection of ibotenic acid (IA) into the Kölliker-Fuse nucleus (KFN) of awake goats. The swallows are categorized as inspiration (I; blue), expiration (E; orange), early-I (gray), and late-E (purple). A trendline is fitted to I and E swallows. Note the slope of the $\theta n+1$ trendlines decreases with increasing injection volumes, indicating there is less phase shifting (i.e., a more negative slope) for I and $\mathrm{E}$ swallows. The linear regression for the control, $1 \mu \mathrm{IA}$, and 10 $\mu \mathrm{l}$ IA studies are as follows: 1) $y=0.0336 x+0.9798$, 2) $y=-0.2024 x+1.0049$, and 3) $y=-0.6493 x$ +1.0133 . Early-I and late-E swallows phase shift in predictable and consistent manners, and were thus not analyzed in this fashion.

We next determined if any phase resetting that occurred persisted in the subsequent respiratory cycles by a $\theta$ subtraction analysis (Fig. 10). This analysis plots the respective $\theta$ subtracted from the succeeding $\theta$ relative to $\varphi$, allowing determination of any $\theta$ differential between the series found in Figure 8B, for example, in addition to those for the 1 and $10 \mu$ IA studies. For all study 
conditions, the $\theta_{n+1}-\varphi$ series changed significantly $(P<0.05)$ with respect to $\varphi$ (Fig. 10), with phase delay by I swallows ( $\varphi=0-0.3$ ), phase advance by early-E swallows ( $\varphi=0.3-0.9)$, and phase delay by late-E swallows $(\varphi>1.1)$. However, the $\theta$ differential was not significantly affected by injection of IA (Fig. 10). Thus, once the resetting of respiratory rhythm had occurred, it persisted in subsequent breaths.
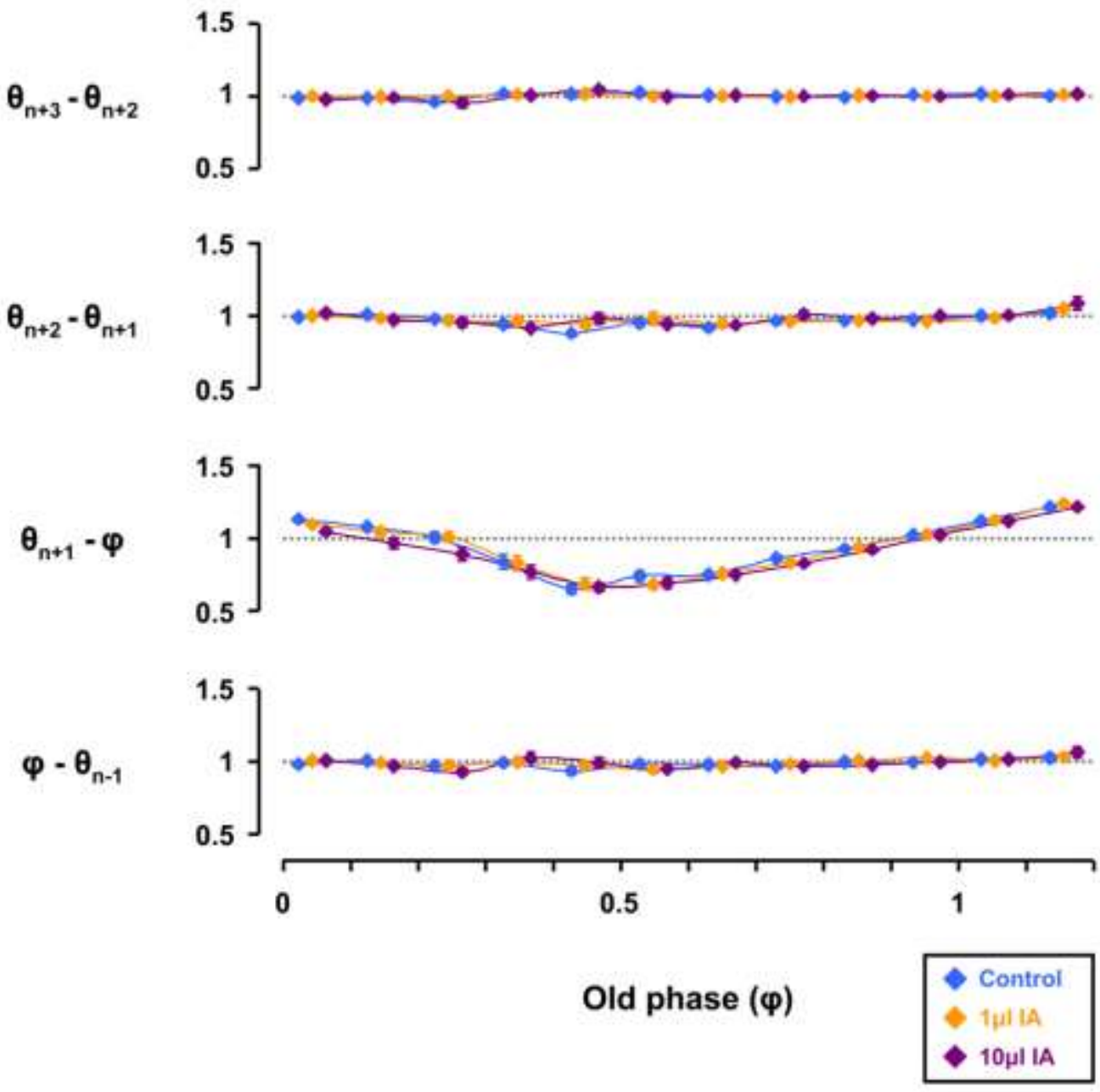

Figure 10. Injections of ibotenic acid (IA) did not significantly effect the difference in cophase $(\theta)$ from the previous $\theta$. Irrespective of study conditions, the ' $\theta_{n+1}-$ old phase $(\varphi)^{\prime}$ series changed significantly $(P<0.05)$ with respect to $\varphi$ by two-way RM ANOVA. Specifically, $\varphi^{\prime}$ 's during the inspiratory phase $(\approx \varphi 0$ to 0.3$)$ were phase delayed, $\varphi$ 's during the early expiratory phase $(\approx \varphi 0.3$ to 0.9$)$ were phase advanced, and $\varphi$ 's during the late expiratory phase $(\approx \varphi>1.1)$ were phase delayed. Note that values $>1$ were phase delayed, values $<1$ were phase advanced, and values $\approx 1$ had no effect on respiratory timing.

Respiratory Physiology \& Neurobiology, Vol 175, No. 2 (February 15, 2011): pg. 272-282. DOI. This article is (C) Elsevier and permission has been granted for this version to appear in e-Publications@Marquette. Elsevier does not grant permission for this article to be further copied/distributed or hosted elsewhere without the express permission from Elsevier. 
NOT THE PUBLISHED VERSION; this is the author's final, peer-reviewed manuscript. The published version may be accessed by following the link in the citation at the bottom of the page.

\subsection{Effects of ibotenic acid injections on breathing with respect to old phase}

In the control study, early-I swallows $(\varphi=0-0.1)$ decreased inspiratory time $\left(\mathrm{T}_{\mathrm{I}}\right)$ in the $n$ and $n+1$ breaths, and decreased $\mathrm{T}_{\mathrm{E}}$ and $V_{\mathrm{T}}$ in the $n$ breath (Fig. 11). I swallows ( $\varphi=0.1-0.3$ ) increased $\mathrm{T}_{\mathrm{I}}$ in the $n$ breath, decreased $\mathrm{T}_{\mathrm{I}}$ in the $n+1$ breath, decreased $\mathrm{T}_{\mathrm{E}}$ in the $n$ breath, and decreased $\mathrm{V}_{\mathrm{T}}$ in the $n$ and $n+1$ breaths (Fig. 11).

Compared to the control study, injection of 1 and $10 \mu$ IA significantly $(P<0.05)$ increased $T_{I}$ and attenuated $T_{E}$ and $V_{T}$ decreases in the $n$ breath of I swallows ( $\varphi=0-0.3)$ and attenuated $T_{I}$ decreases in the $n+1$ breath of I swallows ( $\varphi=0-0.3$ ) (Fig. 11). Under all conditions, early-E swallows $(\varphi=0.3-0.9)$ decreased $\mathrm{T}_{\mathrm{E}}$ in the $n$ breath, and decreased $\mathrm{T}_{\mathrm{I}}$ and $\mathrm{V}_{\mathrm{T}}$ in the $n+1$ breath (Fig. 11). Also under all conditions, late-E swallows $(\varphi>1.1)$ increased $\mathrm{T}_{\mathrm{E}}$ in the $n$ breath (Fig. 11).

Respiratory Physiology \& Neurobiology, Vol 175, No. 2 (February 15, 2011): pg. 272-282. DOI. This article is @ Elsevier and permission has been granted for this version to appear in e-Publications@Marquette. Elsevier does not grant permission for this article to be further copied/distributed or hosted elsewhere without the express permission from Elsevier. 
NOT THE PUBLISHED VERSION; this is the author's final, peer-reviewed manuscript. The published version may be accessed by following the link in the citation at the bottom of the page.
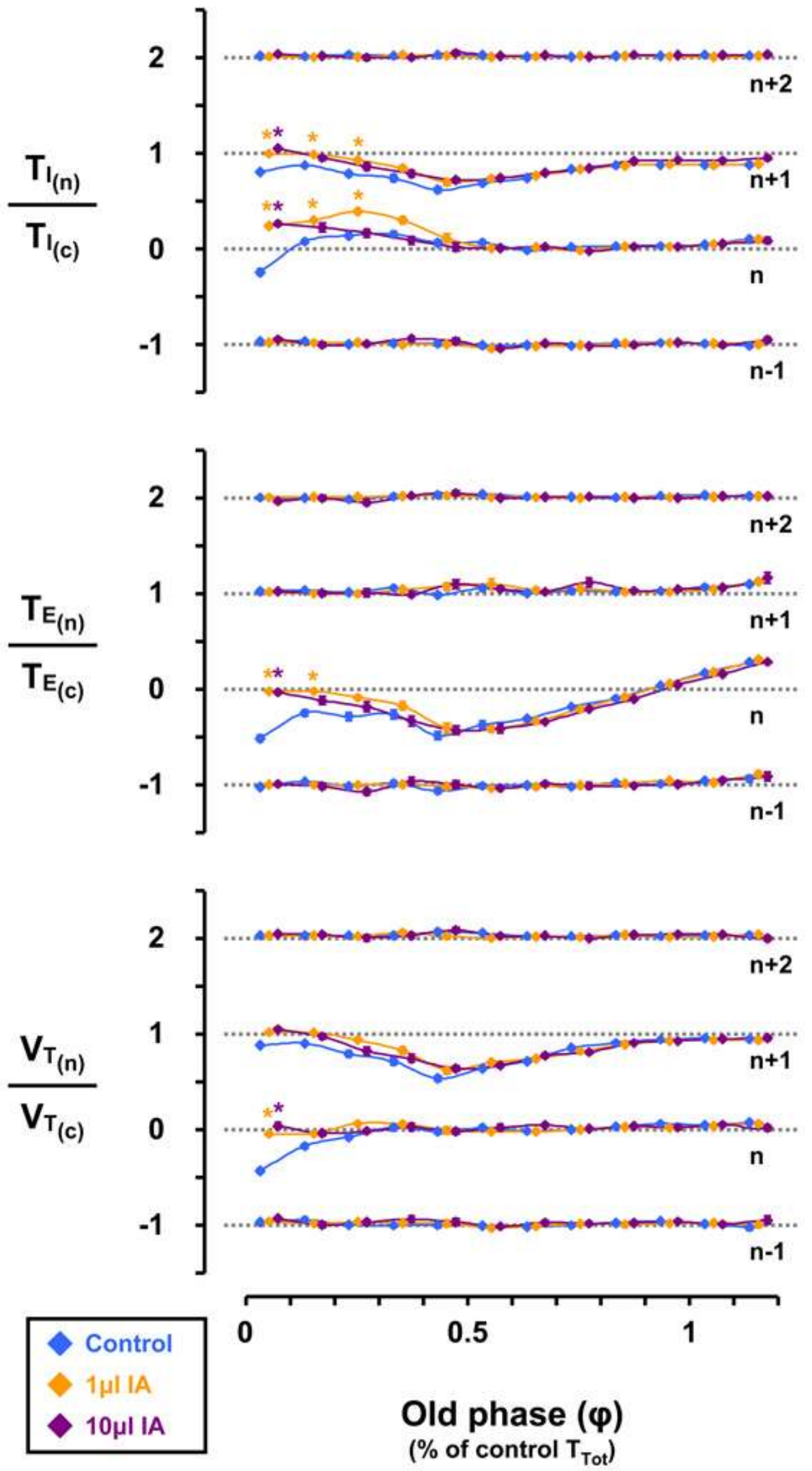
NOT THE PUBLISHED VERSION; this is the author's final, peer-reviewed manuscript. The published version may be accessed by following the link in the citation at the bottom of the page.

Figure 11. Injection of either 1 or $10 \mu$ ibotenic acid $(I A)$ significantly $(P<0.05)$ increased the inspiratory time (TI) and attenuated the expiratory time (TE) and tidal volume $(\mathrm{VT})$ decreases seen in the $\mathrm{n}$ breath of inspiratory swallows $(\approx \varphi 0$ to 0.25$)$ under control conditions. Under all conditions, early-E swallows $(\approx \varphi 0.35$ to 0.9$)$ decreased TE in the $\mathrm{n}$ breath, and decreased TI and VT in the $\mathrm{n}+1$ breath. Also under all conditions, late-E swallows $(\approx \varphi>1.1)$ increased TE in the $\mathrm{n}$ breath. Asterisks denote significant $(P<0.05)$ differences from respective control value.

\section{Discussion}

The results of this retrospective analysis support the concept that dorsolateral pontine neurons contribute to coordination of breathing and swallowing in an unanesthetized, awake animal. Our first hypothesis regarding frequency of occurrence of swallows was validated in that the $10 \mu \mathrm{I}$ IA injection into the dorsolateral pons elicited a transient increase in swallow frequency, largely paralleling the ventilatory response to IA (Bonis et al 2010b). Our second hypothesis regarding attenuation of respiratory phase resetting was validated in that the slope of the $\theta_{n+1}$ linear regression was increasingly negative with increasing volumetric IA injections. Our last hypothesis regarding ventilatory output parameters was validated in that $T_{I}, T_{E}$, and $V_{T}$ were altered from control conditions in the $n$ and/or $n+1$ breath(s) during I swallows $(\varphi=0-0.3)$.

\section{1 Limitations}

A potential limitation of this study was its retrospective nature; thus, the study was not specifically designed to investigate the coordination between swallowing and breathing. However, the study design was appropriate to test our current hypotheses. Another potential limitation is the absence of swallowing and breathing data prior to the surgical implantation of cannula into the pons as conceivably cannula implantation alone may have affected coordination of breathing and swallowing. However, we have previously reported the effects on swallowing and breathing of cannula implantation into multiple medullary sites (Feroah T. et al., 2002b; Fig. 3 ), where no significant differences were found between pre-cannula and post-cannula values. Additional limitations have been described elsewhere including an inability to unequivocally define the anatomic regions affected by IA injections (Bonis J.M. et al., 2010b); thus, the

Respiratory Physiology \& Neurobiology, Vol 175, No. 2 (February 15, 2011): pg. 272-282. DOI. This article is (C) Elsevier and permission has been granted for this version to appear in e-Publications@Marquette. Elsevier does not grant permission for this article to be further copied/distributed or hosted elsewhere without the express permission from Elsevier. 
NOT THE PUBLISHED VERSION; this is the author's final, peer-reviewed manuscript. The published version may be accessed by following the link in the citation at the bottom of the page.

conclusions need to be general to effects of lesions in the dorsolateral pons.

\subsection{Effect of IA on the occurrence of swallows}

The swallowing data reported herein were obtained utilizing nearly the same procedures on goats as in two previous studies on goats by our laboratory (Feroah T. et al., 2002a and 2002b). The occurrence of solitary swallows during the control study (10\% of breaths) herein was relatively comparable to the previous studies ( $15 \%$ of breaths). In this study we found that $10 \mu$ but not $1 \mu \mathrm{l}$ injections of IA into the dorsolateral pons caused a transient increase in the frequency of swallows. This change closely followed the temporal pattern of the change in breathing after the IA injections (Bonis J.M. et al., 2010b). IA is an excitotoxin, meaning it initially binds to glutamate receptors on neurons and excites them as would glutamate, but remains irreversibly bound to the receptor ultimately causing osmotic destruction of the neuron, creating a neuron-specific lesion. During the 5 hours after the IA injections reported herein, it is likely the excitatory phase of IA was initially at least dominant. The transient nature of the response could be due to IA activation of a heterogeneous population of initially excitatory and subsequently inhibitory neurons (Bonis J.M. et al., 2010b). Indeed, Gestreau et al., reported that glutamate injections into the rostral and caudal KFN have stimulatory effects on hypoglossal bursting activity associated with swallowing, whereas glutamate injections into the intermediate KFN have inhibitory effects on hypoglossal bursting activity associated with swallowing (Gestreau C. et al., 2005). An alternative explanation is that transient nature of the increase in swallowing is due to removal of the IA stimulation as the neurons die due to the neurotoxic effect of IA. We interpret the similarity in effects on swallowing and breathing frequency of IA injections as indicative of a "modulatory" role of the dorsolateral pons to respiratory and swallowing pattern generators presumably in the medulla (Jean A. et al., 1996; Kessler J.P. et al., 1990; Bianchi A.L. et al., 1995; Abdala A. et al., 2009).

Respiratory Physiology \& Neurobiology, Vol 175, No. 2 (February 15, 2011): pg. 272-282. DOI. This article is @ Elsevier and permission has been granted for this version to appear in e-Publications@ Marquette. Elsevier does not grant permission for this article to be further copied/distributed or hosted elsewhere without the express permission from Elsevier. 
NOT THE PUBLISHED VERSION; this is the author's final, peer-reviewed manuscript. The published version may be accessed by following the link in the citation at the bottom of the page.

\subsection{Effect of IA on where swallows occur within the respiratory cycle}

The time during the respiratory cycle in which the spontaneous swallows occurred in the control study described herein differed from previous studies. Feroah et al. (Feroah T. et al., 2002a and 2002b) found a nearly coequal distribution of swallows during $E$, late- $E$, and $I$ phases of the respiratory cycle in adult goats, compared to our data showing $2 \%$ of swallows during $E$, $68 \%$ during late-E, and $25 \%$ during I. This distribution was very robust as it persisted throughout the frequency response to IA injections. Moreover, the present distribution is similar to that reported by Dick et al (Dick T.E. et al., 1993) who found in decerebrate, vagotomized, paralyzed cats that fictive swallows induced by superior laryngeal nerve stimulation occurred most prevalently in the E-I transitions. Most studies in adult humans (Clark G., 1920; Nishino T. et al., 1985; Smith J. et al., 1989; Shaker R. et al., 1992; Preksaitis H. et al., 1992) also found a predominance of swallows during E. In addition, Fontana et al (Fontana G.A. et al., 1992) found in humans that the masseter muscle for mastication was activated preferentially at the E-I phase transition. However others (Issa F. et al., 1994; Paydarfar D. et al., 1995) found in adult humans that most spontaneous swallows occur between late-I and mid-E. Criteria used for classifying swallows into the aforementioned categories differed slightly between studies, which may account for a small part of the differences between studies in the timing of swallows.

The importance of the timing of a swallow within the respiratory cycle is in the potential for aspiration and the efficiency of the two behaviors. For example, Paydarfar et al (Paydarfar D. et al., 1995) proposed that "respiratory timing influences the vulnerability for aspiration during deglutition" and the vulnerability is greatest with late-E swallows as the bolus may not have descended sufficiently before inspiration to prevent aspiration. On the other hand, we propose that late-E swallows maximize efficiency of respiration and deglutition as there is normally at rest a pause in airflow during late-E. In other words, in goats late-E swallows suggest proper coordination of the two behaviors and the most energetically-efficient phase to interrupt breathing.

Respiratory Physiology \& Neurobiology, Vol 175, No. 2 (February 15, 2011): pg. 272-282. DOI. This article is (C) Elsevier and permission has been granted for this version to appear in e-Publications@Marquette. Elsevier does not grant permission for this article to be further copied/distributed or hosted elsewhere without the express permission from Elsevier. 
NOT THE PUBLISHED VERSION; this is the author's final, peer-reviewed manuscript. The published version may be accessed by following the link in the citation at the bottom of the page.

\subsection{Effects of IA on swallow induced changes in ventilatory parameters}

Based upon data presented herein, the effects of swallows on ventilatory parameters: 1 ) was dependent upon where the swallow occurred within the respiratory cycle, 2) was restricted to the $n$ and $n+1$ breaths, with no effects in the $n-1$ and $n+2$ breaths, and 3) manifested primarily in changes to $T_{I}$ and $T_{E}$, leading secondarily to changes in $\mathrm{V}_{\mathrm{T}}$. These findings are consistent with the concept that the network for swallowing is hierarchically dominant to the network for breathing, most dramatically demonstrated by a finding that swallows, once initiated continue uninterrupted to completion in a consistent pattern (Dick T.E. et al., 1993). Swallows clearly disrupt breathing as there is a short pause of airflow and diaphragm activity when a swallow occurs during inspiration. Moreover, most swallows during expiration terminate this phase. Other examples are as we found, early-I swallows attenuated $T_{I}, T_{E}$, and $V_{T}$ for that breath, and for all $E$ swallows, $T_{E}$ was altered in the $n$ breath, with secondary attenuation in $\mathrm{V}_{\mathrm{T}}(\varphi=0.3-0.9)$ following in the $n+1$ breath. It is interesting to note that while $T_{I}$ and $T_{E}$ both increased and decreased relative to control depending upon where the swallow occurred within the respiratory cycle, the secondary effect was a decrease and not a compensatory increase in $\mathrm{V}_{\mathrm{T}}$. This particular finding is again consistent with the reasoning that swallows are hierarchically dominant to breathing, and that $\mathrm{V}_{\mathrm{T}}$ and presumably gas exchange are compromised in deference to the effects of swallows on timing, consistent with the observations of others (Feroah T. et al., 2002a and 2002b; Paydarfar D. et al., 1995). Finally, the $10 \mu \mathrm{I}$ IA injection reduced the normal swallow induced lengthening of $T_{E}$ and $T_{I}$ which exacerbated the swallowinduced decrease in $\mathrm{V}_{\mathrm{T}}$, suggesting that this perturbation enhanced the normal dominance of the swallow pattern generator over the respiratory pattern generator.

\subsection{Effects of IA on swallow induced resetting of the respiratory rhythm}

During the control study, E and I swallows caused a complete resetting of the respiratory rhythm. However, 1 and $10 \mu \mathrm{IA}$ injections into the dorsolateral pons progressively attenuated this phase shift

Respiratory Physiology \& Neurobiology, Vol 175, No. 2 (February 15, 2011): pg. 272-282. DOI. This article is @ Elsevier and permission has been granted for this version to appear in e-Publications@ Marquette. Elsevier does not grant permission for this article to be further copied/distributed or hosted elsewhere without the express permission from Elsevier. 
(Fig. 9). Operating within the concept that the network for swallowing is normally dominant to the network for breathing, it follows that IA injections preferentially modulated the network controlling swallowing, weakening the dominance of a swallow to reset respiratory rhythm. In other words, while swallows were not completely inhibited, their ability to reset the respiratory rhythm was not as robust as under control conditions, indicating that dorsolateral pontine neurons are normally a major determinant of this component of the hierarchical dominance of the swallowing network. This effect contrasts to the IA induced augmented dominance in swallow pattern generation described above.

\subsection{The relationship between the neural networks for swallowing and breathing}

The central pattern generator for swallowing has classically been thought of as a group of neurons dedicated to this particular behavior (Bianchi A.L. et al., 1995; Jean A. et al., 1996). Recent thinking favors a more distributed neural network, or holarchical system, capable of reorganizing such to provide motor output for multiple, hierarchically organized and coordinated behaviors, including swallowing and breathing (Bolser D. et al., 2006). Our unique, intact preparation allows observation of spontaneous swallows amidst other physiologically normal behaviors, with the additional ability to neurotoxically lesion and then study the animal during wakefulness. The capacity of this preparation to observe both the normal and disrupted neural network underlying swallowing and breathing facilitates meaningful extrapolations to both normal humans and patients suffering from dysphagia.

The data reported herein are consistent with the concept of a modulatory role for dorsolateral pontine neural circuits subserving both swallowing and breathing. Since $10 \mu \mathrm{l}$ IA injection strengthened swallow pattern generation over respiratory pattern generation but had opposite effect on the normal swallow dominance in rhythm generation, it appears there is differential dorsolateral pontine modulation to two distinct aspects of the neural circuit. In addition, we find no evidence to support the concept of a single central swallow pattern generator within or near the dorsolateral pons, and our findings are not inconsistent with the concept that the dorsolateral

Respiratory Physiology \& Neurobiology, Vol 175, No. 2 (February 15, 2011): pg. 272-282. DOI. This article is @ Elsevier and permission has been granted for this version to appear in e-Publications@Marquette. Elsevier does not grant permission for this article to be further copied/distributed or hosted elsewhere without the express permission from Elsevier. 
pons is part of a holarchical network regulating both swallowing and breathing. These data do not provide insight into the specific substrate (neuronal subpopulation) within the dorsolateral pons contributing to these effects, but the data of Dick et al (Dick T.E. et al., 1993) and Dutschmann and Herbert (Dutschmann M. et al., 2006) implicate postinspiratory KFN neurons as contributors to respiratory phase transitions and interactions of swallowing and breathing.

Acknowledgements: This study was supported by the Department of Veterans Affairs and National Heart, Lung, and Blood Institute Grants HL25739 and HL-007852.

Publisher's Disclaimer: This is a PDF file of an unedited manuscript that has been accepted for publication. As a service to our customers we are providing this early version of the manuscript. The manuscript will undergo copyediting, typesetting, and review of the resulting proof before it is published in its final citable form. Please note that during the production process errors may be discovered which could affect the content, and all legal disclaimers that apply to the journal pertain.

\section{References}

Abdala A, Rybak I, Smith J, Zoccal D, Machado B, St. John W, Paton J. Multiple pontomedullary mechanisms of respiratory rhythmogenesis. Respir. Physiol. Neurobiol. 2009;168:19-25.

Bianchi AL, Denavit-Saubie M, Champagnat J. Central control of breathing in mammals: neuronal circuitry, membrane properties, and neurotransmitters. Physiol. Rev. 1995;75:1-26.

Bolser DC, Poliacek I, Jakus J, Fuller DD, Davenport PW. Neurogenesis of cough, other airway defensive behaviors and breathing: A holarchical system? Respir. Physiol. \& Neurobiol. 2006;152:255-265.

Bonis JM, Neumueller SE, Krause KL, Kiner T, Smith A, Marshall BD, Qian B, Pan LG, Forster HV. A role for the Kölliker-Fuse nucleus in cholinergic modulation of breathing at night during wakefulness and NREM sleep. J. Appl. Physiol. 2010a;109:159-170.

Bonis JM, Neumueller SE, Krause KL, Kiner T, Smith A, Marshall BD, Qian B, Pan LG, Forster HV. Site-specific effects on respiratory rhythm and pattern of ibotenic acid injections in the pontine respiratory group of goats. J. Appl. Physiol. 2010b;109:171-188.

Clark GA. Deglutition apnoea. J. Physiol. (Lond) 1920;54:59.

Respiratory Physiology \& Neurobiology, Vol 175, No. 2 (February 15, 2011): pg. 272-282. DOI. This article is @ Elsevier and permission has been granted for this version to appear in e-Publications@Marquette. Elsevier does not grant permission for this article to be further copied/distributed or hosted elsewhere without the express permission from Elsevier. 
NOT THE PUBLISHED VERSION; this is the author's final, peer-reviewed manuscript. The published version may be accessed by following the link in the citation at the bottom of the page.

Dick TE, Oku Y, Romaniuk JR, Cherniack NS. Interaction between central pattern generators for breathing and swallowing in the cat. 1993;465:715-730.

Dutschmann M, Herbert $\mathrm{H}$. The Kölliker-Fuse nucleus gates the postinspiratory phase of the respiratory cycle to control inspiratory offswitch and upper airway resistance in rat. 2006;24(4):1071-1084.

Feroah TR, Forster HV, Fuentes CG, Lang IM, Beste D, Martino P, Pan L, Rice T. Effects of spontaneous swallows on breathing in awake goats. J. Appl. Physiol. 2002a;92:1923-1935.

Feroah TR, Forster HV, Fuentes CG, Wenninger J, Martino P, Hodges M, Pan L, Rice T. Contributions from rostral medullary muclei to coordination of swallowing and breathing in awake goats. J. Appl. Physiol. 2002b; 93:581-591.

11. Fontana GA, Pantaleo T, Bongianni F, Cresci F, Viroli L, Sarago G. Changes in respiratory activity induced by mastication in humans. $1992 ; 72(2): 779-786$.

Gestreau C, Dutschmann M, Obled S, Bianchi AL. Activation of XII motoneurons and premotor neurons during various oropharyngeal behaviors. Respir. Physiol. Neurobiol. 2005;147:159-176.

Issa FG, Porostocky S. Effects of continuous swallowing on respiration. Respir. Physiol. 1994;95(2):181-193.

Jean A, Car A, Kessler JP. Neural Control of the Respiratory Muscles. New York: CRC; 1996. Brainstem organization of swallowing and its interaction with respiration.

Kessler JP, Cherkaoui N, Catalin D, Jean A. Swallowing responses induced by microinjection of glutamate and glutamate agonists into the nucleus tractus solitarius of ketamine-anesthetized rats. Exp. Brain Res. 1990;83:151-158.

Krause K, Forster HV, Kiner T, Davis SE, Bonis JM, Qian B, Pan LG. Normal breathing pattern and arterial blood gases in awake and sleeping goats after near total destruction of the presumed pre-Bötzinger complex and the surrounding region. J. Appl. Physiol. 2009;106:605-619.

Mallios V, Lydic R, Baghdoyan $\mathrm{H}$. Muscarinic receptor subtypes are differentially distributed across brain stem respiratory nuclei. Am J Physiol Lung Cell Mol Physiol. 1995;268:L941-L949.

Martino P, Davis S, Opansky C, Krause K, Bonis J, Pan L, Qian B, Forster HV. The cerebellar fastigial nucleus contributes to $\mathrm{CO}_{2}-\mathrm{H}^{+}$ventilatory sensitivity in awake goats. Respir. Physiol. Neurobiol. 2007;157:242251.

Matsuo K, Palmer J. Coordination of mastication, swallowing and breathing. Jpn Dent. Sci. Rev. 2009;45(1):31-40.

Respiratory Physiology \& Neurobiology, Vol 175, No. 2 (February 15, 2011): pg. 272-282. DOI. This article is (C) Elsevier and permission has been granted for this version to appear in e-Publications@Marquette. Elsevier does not grant permission for this article to be further copied/distributed or hosted elsewhere without the express permission from Elsevier. 
NOT THE PUBLISHED VERSION; this is the author's final, peer-reviewed manuscript. The published version may be accessed by following the link in the citation at the bottom of the page.

Nishino T, Yonezawa T, Honda Y. Effects of swallowing of the pattern of continuous respiration in human adults. Am. Rev. Respir. Dis. $1985 ; 132(6): 1219-1222$.

Paydarfar D, Eldridge FL, Kiley JP. Resetting of mammalian respiratory rhythm: existence of a phase singularity. Am. J. Physiol. Regulatory Integrative Comp. Physiol. 1986;250:721-727.

Paydarfar D, Gilbert RJ, Poppel CS, Nassab PF. Respiratory phase resetting and airflow changes induced by swallowing in humans. J. of Physiol. $1995 ; 483.1: 273-288$.

Prasse JE, Kikano GE. An overview of pediatric dysphagia. Clin. Pediatr. (Phila) 2009;48(3):247-251.

Preiksaitis HG, Mayrand S, Robins K, Diamant NE. Coordination of respiration and swallowing: effect of bolus volume in normal adults. Am. J. Physiol. 1992;263(3 Pt 2):624-630.

Schindler A, Ginocchio D, Ruoppolo G. What we don't know about dysphagia complications? Rev. Laryngol. Otol. Rhinol. (Bord) 2008;129(2):7578.

Shaker R, Li Q, Ren J, Townsend WF, Dodds WJ, Martin BJ, Kern MK, Rynders A. Coordination of deglutition and phases of respiration: effect of aging, tachypnea, bolus volume, and chronic obstructive pulmonary disease. Am. J. Physiol. 1992;263(5 Pt 1):750-755.

Smith J, Wolkove N, Colacone A, Kreisman H. Coordination of eating, drinking and breathing in adults. Chest. 1989;96:578-582.

Wenninger J, Pan L, Klum L, Leekley T, Bastastic J, Hodges M, Feroah T, Davis S, Forster HV. Large lesions in the pre-Bötzinger complex area eliminate eupneic respiratory rhythm in awake goats. J. Appl. Physiol. 2004;97:1629-1636.

Respiratory Physiology \& Neurobiology, Vol 175, No. 2 (February 15, 2011): pg. 272-282. DOI. This article is (C) Elsevier and permission has been granted for this version to appear in e-Publications@Marquette. Elsevier does not grant permission for this article to be further copied/distributed or hosted elsewhere without the express permission from Elsevier. 